\title{
A review of the occurrence of non-alkaloid constituents in Uncaria species and their structure-activity relationships
}

\author{
Ndagijimana Andre ${ }^{1,3}$, Xiaoming Wang ${ }^{1}$, Yongzhi He ${ }^{1}$, Guixiang Pan ${ }^{1,}$ *Agyemang Kojo , \\ Ying Liu ${ }^{1,2}$ \\ ${ }^{1}$ Tianjin State Key Laboratory of Modern Chinese Medicine, Tianjin University of Traditional Chinese Medicine, Tianjin, China \\ ${ }^{2}$ Tianjin International Joint Academy of Biotechnology and Medicine, Tianjin, 300457, PR China \\ ${ }^{3}$ Institute of Scientific and Technological Research (IRST), Rwanda
}

\section{Email address:}

guixiangp@163.com (G. Pan)

\section{To cite this article:}

Ndagijimana Andre, Xiaoming Wang, Yongzhi He, Guixiang Pan, Agyemang Kojo, Ying Liu. A Review of the Occurrence of Non-Alkaloid Constituents in Uncaria Species and Their Structure-Activity Relationships. American Journal of Biomedical and Life Sciences. Vol. 1, No. 4, 2013, pp. 79-98. doi: 10.11648/j.ajbls.20130104.13

\begin{abstract}
A good understanding of a medicinal plant is based on fundamental knowledge of its chemical constituents and their pharmacological effects. The non-alkaloids constituents isolated from Uncaria species have been increasingly investigated recently. The anti-inflammatory, anti-oxidant and anti-cancer properties have been studied in many non-alkaloids constituents isolated from Uncaria species. This paper emphasizes the phytochemical and chemotaxonomic analyses of non-alkaloid constituents isolated from fifteen Uncaria species. Their structural activity-relationships have also been discussed.
\end{abstract}

Keywords: Uncaria Species, Flavonoids, Pentacyclic Terpenoids, Structure-Activity Relationships

\section{Introduction}

About fifteen Uncaria species are widely used in various folk medicines and have thereby been extensively studied for their chemical components and pharmacological effects by different authors. In Peru, $U$. tomentosa is believed to have magical healing power and has been widely investigated. The plant is mainly used for the treatment of asthma, cancer, cirrhosis, fevers, gastritis, diabetes, rheumatism, dysentery and inflammation of urinary tract [1,2]. In Asia, U. rhynchophylla, U. guianensis, U. sinensis, $U$. macrophylla and $U$. hirsuta are popularly used as an antidiabetic, immune system stimulant and a hypo-cholesterol agent to reduce the risk of stroke, heart attack and hypertension [1]. In Malaysia, the more common representatives of Uncaria genera include $U$. gambir, $U$. acida, U. cordata, U. longiflora, U. lucida and $U$. callophylla.

Indole alkaloids constituents were reported to be the major active components of Uncaria species [3] and were extensively studied for their pharmacological activities [4]. However, many other chemical studies have also led to the isolation of non-alkaloids constituents such as flavonoids, phenols and pentacyclic triterpenes. Their pharmacological activities have been also demonstrated. This paper opens a possibility to discuss the phytochemical analysis and structure-activity relationships of the major non-alkaloid constituents isolated from Uncaria species.

\section{Main Classes of Non-Alkaloids Isolated from Uncaria Species}

Non-alkaloids phytochemicals constitute a vast group of plant compounds, ranging from simple structures with one aromatic ring to highly complex polymeric natural products such as tannins. One interesting group of structures in Uncaria genus is the pentacyclic terpenoids, mainly based on ursolic, oleanolic or quinovic acid structures $[5,6]$. Monoterpene compounds such as C-8-(S) isomers of deoxyloganic acid (7-deoxyloganic acid) have also reported from Uncaria plants species [7]. The phenolic compounds are characterized at least by one aromatic ring substituted by at least one hydroxyl group; free or engaged in another function such as ether, ester or glycoside [8].

Various structural types of flavonoids have also been identified in the Uncaria species. Flavonoids are 
polyphenolic compounds, ubiquitous in plants, most significantly in vegetables, fruits, seeds, nuts and beverages such as tea and wine. They are characterized by a chromane type skeleton with a phenyl substituent in the $\mathrm{C}-2$ or $\mathrm{C}-3$ position $\left(\mathrm{C}_{6}-\mathrm{C}_{3}-\mathrm{C}_{6}\right)$, occurring mainly as $O-$ and $\mathrm{C}$-glycosides (hexoses, deoxyhexoses and pentoses), less frequently as aglycons and can be hydroxylated in 3, 5, 7, 3', 4' and/or 5' position. It hydroxyl substituents might also be methylated, acetylated, prenylated or sulphated $[9,10]$. Included in this class of compounds are isoflavonoids (1, 2-diarypropanes) and neoflavonoides (1,1-diarylpropanes). All these classes are derived from the most common group of compounds; flavones, which possess an oxygen bridge between the ortho position of the first ring of benzene and the benzylic carbon atom adjacent to the second ring (Scheme2).

Terpenoids are compounds typically derived from the isoprene unit. This group includes different aromatic compounds, vitamins and steroids. Terpenoids could be classified according to the number of isoprene units that make up the molecular structure. They include hemiterpenes (1 unit), monoterpenes (2 units), sesquiterpenes (3 units), diterpenes (4 units), sesterpenes (5 units), triterpenes (6 units), carotenes (8 units), and polyisoprenes (n units) [11].

The flavonoids identified in the Uncaria genus could be divided into five main classes namely: flavones derivatives (I), flavanones (II), simple phenolic compounds (IIIa and IIIb), (Figure 1, Table 1), and flavane derivatives (IV) particularly flavan-3-ols and their dimmers (Figure 2, Table 2 ). The sugar moieties of these flavonoid glycosides are made up of glucose, galactose and rhamnose [6]. Terpenes constituents classified as pentacyclic triterpenoids $(\mathrm{V})$ and triterpenes saponin (VI) have been also reported in various Uncaria genus [12] (Figure 3, Table 3). Pentacyclic triterpene esters, such as uncarinic acids A-E [13], triterpenoids, including 6 6 -hydroxyursolic acid, $3 \beta, 6 \beta$, $19 \alpha$-trihydroxyurs-12-en-28-oic acid, and $3 \beta, 6 \beta$, 23-trihydroxyurs-12-en-28-oic acid as well as phytosterols such as $\beta$-sitosterol and daucosterol have been isolated from the hooks and leaves of $U$. rhynchophylla [6]. Steroids (VII), coumarins (VIII) and lignans (IX) [5] have also been identified from various Uncaria species (Figure 4, Table 4).

\subsection{Biosynthesis}

The biosynthetic pathway of phenolics constituents have been proposed (Scheme 1). The shikimic acid pathway leading from monosacharides to aromatic amino acids (tyrosine and phenylalanine), then by deamination of the first, to cinnamic acids and their derivatives such as benzoic acids, lignanes and coumarins [14]. Another biosynthesis pathway starting with acetate and leading to poly-ketoesters, which by cyclization forms polycyclic products, including xanthones and quinines (Scheme 2) have also been suggested [14-16].

\subsection{Relative Abundance}

The Uncaria species contain phenolic compounds at different proportions. According to Valente et al 2009 [17], the presence of kaempferitrin in the leaves and stems of $U$. guianensis were at a ratio of almost thirty six times in the leaves than in the stems and was completely absent in the bark of this plant. However, kaempferitrin was not found in the leaves and bark of $U$. tomentosa. These results reveal the selectivity of $U$. guianensis to produce kaempferitrin as a bioactive flavonoid glycoside. Kaempferitrin has therefore been suggested as a potential chemical marker for the species. The elucidation of the individual chemical markers for various Uncaria species is therefore a possibility for their specific identification.

Sun G.L et al. 2012 [5] reported the isolation and identification of stereo-structure of lignans from $U$. sinensis. About ca. 12\% and up 48\% procyanidines has been isolated from the bark and dry extracts of $U$. tomentosa, respectively. $\beta$-Sitosterol (ca. 60\%) was identified as a major sterol in the plant. Sterols include stigmasterol and campesterol [18] and quinovic acid glycosides with various glycosylation sites have also been reported in various Uncaria species [19,20]. Trifolin [6,21], kaempferol- $\alpha$-L-rhamnopyranosyl- $(1 \rightarrow 6)-\beta$-Dglucopyranoside[6,22], rutin [6], quercetin-3-O- $\alpha-\mathrm{L}-$ rhamnopyranosyl-( $1 \rightarrow 6)-\beta-D-$ galactopyranoside $[6,22]$, hyperin [6,22], quercetin [23] and hyperoside [6] have been identified as the major flavonoids in U. rhynchophylla.

Li et al 2011[24] described a method for the isolation of non-alkaloids components including flavonoids, terpenes, anthraquinone and aromatic compounds. The dried and powdered bark and branch with curved hooks of $U$. sinensis were exhaustively extracted with $70 \%$ ethanol. Then, the aqueous fraction was sequentially partitioned with petroleum ether, $\mathrm{CHCl}_{3}, \mathrm{EtOAc}$ and $\mathrm{n}-\mathrm{BuOH}$. These fractions were repeatedly subjected to column chromatography on silica gel, Sephadex LH-20 gel and reversed phase $\mathrm{C} 18$ gel to yield pure pentacyclic terpenoids and flavonoids compounds. Many other extraction procedures involving a succession of solvents of increasing polarity and chromatographic technical methods have been reported in various other phytochemistry studies of Uncaria species [19,20,25,26].

\section{Pharmacological Activities}

Pharmacological application and use of phenolic containing herbs are closely related to their biosynthetic origin and the chemical structure of the active components $[1,27]$. The antioxidant properties of Uncaria species are attributed to the presence of polyphenols such as tannins, catechin, gambiriins [28]. The pharmacological effects of polyphenolics have also been reported in many other plant species. Pine bark extract notably rich in polyphenols such as catechin, quercetin, dihydroquercetin, taxifolin and phenolic acids, has been reported to be effective in 
suppressing postprandial hyperglycemia in diabetics [29].The ethyl acetate extract of Hypericum japonicum has been proven to have antihypoxic activity. Quercetin derivatives have been the most notable flavanoids type associated with these activity [30].

Various pharmacological studies have reported the antioxidant and anti-inflammatory properties of the phenol fractions of Uncaria species prepared from polar solvents such as methanol or water/ethanol mixture [31]. Their cytotoxic effect and potential to inhibit the proliferation of human cancer cells have also been demonstrated $[13,32]$. Further pharmacological studies have established the chemical structure-activity relationships for a number of pure flavonoids and pentacyclic terpenoids isolated from Uncaria species.

\subsection{Flavonoids Constituents}

The natural flavonoids of Uncaria species have exhibited large varieties of biological activities. They have showed significant anti-inflammatory, and antioxidant activities, and anti-glycation inhibitory activity [33-35]. Many flvonoids have also showed remarkable role on carcinogen activation in vivo and on carcinogenesis [36,37].

Rosmarinic acid, protocatechuic acid, trans-caffeic acid and quercetin-3-O- $\beta$-D-gluco- pyranoside (9) were found to have high antioxidant activities, with $\mathrm{IC}_{50}=13.5,14.1$, 16.3 and $19.1 \mu \mathrm{M}$, respectively [33]. The antioxidant potential of kaempferol-3-O- $\alpha$-L-rhamno- pyranosyl $(1 \rightarrow 6)-\beta$-D-glucopyranoside $(6) \quad\left(\mathrm{IC}_{50}=39.5 \mu \mathrm{M}\right)$ and kaempferide-3-O- $\alpha$-L- rhamnopyranosyl $(1 \rightarrow 6)-\beta$-Dglucopyranoside $(13)\left(\mathrm{IC}_{50}=42.4 \mu \mathrm{M}\right)$ have also been studied in comparison to that of butylated hydroxyanisole (BHA) $\left(\mathrm{IC}_{50}=44.3 \mu \mathrm{M}\right)$ [38]. Gallic acid (27) and (-)-epi-gallocatechin-3-O-gallate (59) showed a strong anti-oxidative activities with concentrations of 28.16 and $22.97 \mu \mathrm{M}$, respectively, in comparison with reference antioxidants such as ascorbic acid ( $\left.\mathrm{IC}_{50} 56.25 \mu \mathrm{M}\right)$, BHA $\left(\mathrm{IC}_{50} 91.15 \mu \mathrm{M}\right)$ and butylated hydroxytoluene $(\mathrm{BHT})\left(\mathrm{IC}_{50}\right.$ $66.83 \mu \mathrm{M})$. Kaempferol, kaempferol 7-O- $\alpha-\mathrm{L}-$ rhamnopyranoside and herbacetin7-O- $\alpha-\mathrm{L}-$ rhamnopyramosyde (20) showed moderate antioxidative activities with $\mathrm{IC}_{50}$ values of $50.51,87.42$ and $48.34 \mu \mathrm{M}$, respectively [39]. Cytotoxicity studies using the brine shrimp demonstrated an $\mathrm{LC}_{50}$ values of 3.19 and 5.86 $\mu \mathrm{g} / \mathrm{mL}$ for acute and lethal doses respectively indicating extreme toxicity compared to the reference drug, cyclophosphamide ( $\mathrm{LC}_{50}$ value of $25.06 \mu \mathrm{g} / \mathrm{mL}$ ) [40].

The antioxidant activity of flavonoids depends upon the arrangement of functional groups about the nuclear structure $[41,42]$. The ortho-dihydroxy (catechol) structure in rosmarinic acid, protocatechuic acid, trans-caffeic acid plays an important role in their antioxidative function as in quercetin-3-O- $\beta$-D-glucopyranoside, and this can further explain the weak scavenging activity $\left(\mathrm{IC}_{50}=53.4 \mu \mathrm{M}\right)$ of kaempferol-3-O- $\beta$-D-glucopyranoside which lacks the B-ring catechol system [43]. Furthermore, the reduced antioxidant activity of kaempferide-3-O- $\beta-D$ - glucopyranoside $\left(\mathrm{IC}_{50}=55.5 \mu \mathrm{M}\right)$ [33] could be attributed to 4'-O-methylation that perturbs ring planarity through steric effects. On the contrary, kaempferide-3-O- $\beta-D-$ glucopyranoside and kaempferol-3-O- $\beta$-D-glucopyranoside showed remarkable anti-inflammatory activities showing 62.4 and 59 percent inhibition, respectively. The effect of protocatechuic acid $(55.0 \%)$ was comparable to that of the reference compound (57.6\%). Other compounds have been displayed lower percentages of inhibition activity in the $38.4-51.2 \%$ range [33].

The inhibitory effect of caffeic methyl ester on 5-lipoxygenase $\left(I D_{50}=4.810^{-7} M\right)$ was stronger than that of caffeic acid itself $\left(I D_{50}=3.710^{-6} M\right)$. Caffeic acid and its methyl ester did not inhibit prostaglandin synthase activity at all, at least up to $510^{-4} \mathrm{M}$, but rather stimulated it at higher doses. The biosynthesis of leukotriene $\mathrm{C}_{4}$ and $\mathrm{D}_{4}$ in mouse mast tumor cells was also inhibited completely with $10^{-4} \mathrm{M}$ caffeic acid. Platelet aggregation induced by arachidonic acid was also inhibited by caffeic acid at high dose, while platelet aggregation induced by ADP was not influenced by caffeic acid at all [44].

Studies have demonstrated the protective effect of some polyphenols (epicatechin, catechin and caffeic acid) from the aqueous extracts of $U$. sinensis against erythrocyte membrane hemolysis inflicted by 2,2-azo-bis-(2-amidinopropane)-dihydrochlroride [45]. Rutin, another flavonoid found in the leaves of U.hirsuta has been used for treatment of blood capillary ailments [46]. Curcumin, rutin, garcinol and arbutin have also been found to have strong anti-glycation activity and antioxidative properties $[47,48]$.

Zhao and Zhang, 2009 [49] reported the cytoprotective effects of kaempferol, quercetin and myricetin, against human hepatocytes (HL-7702 cell line) oxidative injury induced by $\mathrm{H}_{2} \mathrm{O}_{2}$ or $\mathrm{CCl}_{4}$. The potency of cytoprotective effect of these three flavonoids evaluated qualitatively was reported in the order of quercetin $>$ myricetin $>$ kaempferol. The structure-activity relationship between the numbers of hydroxyl group in the ring B of the compounds and their cytoprotective effect could not be clearly established [49].

Myricetin and quercetin constitute an important group of phytochemicals that have gained increased research attention after their reported anticarcinogenic, antimutagenic, anti- inflammatory, and antiviral actions[50]. It has been shown that, quercetin and myricetin structures differ only by a hydroxyl group at the myricetin 5' position, giving rise to an easy release of an additional reducing agent from the B-ring hydroxyls to form a more stable $O$-quinone [51]. A better protective effect of myricetin than quercetin against heterocyclic amines-induced oxidative DNA damage in human hematoma cells has been reported [52]. This indicates that the only an additional hydroxyl group at position $5^{\prime}$ in the chemical structure of myricetin could have significantly affect the biological activity against heterocyclic amines. This evidence proves the close relationship between the numbers of hydroxyl groups in their structure to their protective effect of flavonols. 
Quercetin, quercetin-3-O- $\alpha$-L-rhamnopyranosy- $(1 \rightarrow 6)$ $\beta$-D-galactopyranoside and quercetin-3-O- $\beta$-Dgalactopyranside, isolated from $U$. sinensis have been shown to have a dose dependent inhibitory effect on $\alpha$-glycosidase. Several other pharmacological properties such as free radical scavenging, anti-oxidation, immunomodulation, insulin sensitization and protection of various organs have also been reported [53]. These potentials are importatant in describing $U$. sinensis as antidiabetic an agent. In another experiment, quercetin together with other major phenolic compounds isolated from Saussurea medusa were tested for their protective activity against hydrogen peroxide $\left(\mathrm{H}_{2} \mathrm{O}_{2}\right)$-induced damage in rat pheochromocytoma line $\mathrm{PC} 12$ cells. The results showed that quercetin possesses moderate protective activities against $\mathrm{H}_{2} \mathrm{O}_{2}$-induced cell damage [54].

The in vitro antioxidant activity of flavonoids could also be increased by polymerization of their monomers. Typical examples include proanthocyanidins (also known as condensed tannins), the polymers of catechins proven to be excellent in vitro antioxidants due to the high number of hydroxyl groups in their molecules. The antioxidant capacity of proanthocyanidins depends on their oligomer chain length and the type of reactive oxygen species with which they are react [55].

The neolignan group has exhibited extensive activities, such as anti-tumor, antiviral and protection of the liver and inhibition of platelet activation factor. A related lignin compound, (+)-Lyoniresinol-3 $\alpha-O-\beta$-d-glucopyranoside isolated from the root bark of Lycium chinense Miller, exhibited potent antimicrobial activity against antibiotic-resistant bacterial strains, methicillin resistant Staphylococcus aureus isolated from patients, and human pathogenic fungi without having any hemolytic effect on human erythrocytes. In addition, this compound induced the accumulation of intracellular trehalose on $C$. albicans as stress response to the drug, and disrupted the dimorphic transition that forms pseudo-hyphae as a result of the pathogenesis [56].

\subsection{Pentacyclic Terpenoids}

The structure elucidation of terpenoid compounds and their pharmacological effects have been extensively studied $[13,57]$. In a bioactivity-guided fractionation studies, the $\mathrm{CHCl}_{3}$ extract of the hooks of $U$. rhynchophylla, which showed potent inhibitory activity against phospholipase $\mathrm{C} \gamma 1$ (PLC $\gamma 1$ ) led to the isolation of eight tepenoids compounds namely uncarnic acid C (70), uncarinic acid D (71), Uncarinic acid E (72), 3 $\beta$-hydroxy-27-p-(Z)-coumaroyloxyolean-12-en-28-oic acid (73), 3ß-hydroxy-27-p-(E)-coumaroyloxyurs12-en-28-oic acid (75), 3ß-hydroxy-27-p-(Z)coumaroyloxyurs-12-en-28-oic acid (74), uncarinic A (68) and uncarinic B (69) [13,58]. All these compounds exhibited dose dependent inhibition of PLC $\gamma 1$, with $\mathrm{IC}_{50}$ of 9.5-44.6 $\mu \mathrm{M}$. From these results, some preliminary structure-PLC $\gamma 1$ inhibitory activity relationships have been deduced. The compounds having an ursane moiety were shown to be more active than those having an oleanane moiety $(70>68,71>69,75>72$ and $74>73)$. Furthermore, the compounds possessing a trans configuration were more effective than those possessing a cis configuration $(70>71$, $72>73,75>74$ and $68>69$ ), and the compounds containing a p-coumaroyloxy group were more potent than those containing a feruloyloxy group $(75>70,74>71,72>68$ and $63>69)$. Compound 75 , which contains an ursane moiety, a trans configuration, and a $p$-coumaroyloxy moiety, showed the most powerful inhibitory activity, with an $\mathrm{IC}_{50}$ value of $9.5 \mu \mathrm{M}$, in comparison to amentoflavone $\left(\mathrm{IC}_{50}\right.$ of $\left.29.0 \mu \mathrm{M}\right)$.

In another study, the systematic structure-activity relationship of (75) and their derivatives (Scheme 3) with PLC $\gamma 1$ were investigated [59]. An acetate of 7 (75-1) was entirely ineffective $\left(\mathrm{IC}_{50}:>250 \mu \mathrm{M}\right)$, while the methyl ester (75-2) and the reduced form at the $2^{\prime}$ double bond (75-3) exhibited lower inhibitory activities than 75 , with $\mathrm{IC}_{50}$ values of 121.3 and $83.6 \mu \mathrm{M}$, respectively. Compound 75-4 and p-E-coumaric acid (75-5) did not show inhibitory activity $\left(\left(\mathrm{IC}_{50}:>250 \mu \mathrm{M}\right)\right.$. These results observed concluded that 3-OH, 7' $\mathrm{OH}, 28-\mathrm{COOH}, 2{ }^{\prime}$ double bond and esterification of triterpene and p-E-coumaric acid may be important for PLC $\gamma 1$ inhibitory activity. Furthermore, the compounds possessing a $p$-coumaroyloxy at position 27 rather than at the 3 and 28 positions showed the greatest inhibitory activity against PLC $\gamma 1$. The facts that the pentencyclic terpenes isolated from $U$. rhynchophylla showed dose-dependent inhibitory activities against PLC $\gamma 1$ in vitro and inhibited the proliferation of human cancer cells suggest that these compounds could be chemical lead for further development into cancer chemopreventive or chemotherapeutic agents with lower toxicity against normal tissues.

Umeyama A et al, 2010 [60], explained how uncarinic acids $C$ and $D$ influenced the initiation of specific immune responses at a dendritic cells (DC) level, allowing the DC to function as highly professional antigen-presenting cells (APC) for $\mathrm{T}$ cells. Those compounds isolated from the hooks of $U$. rhynchophylla have shown active phenotypic and cytokine production modulatory effects in DC. They have also been shown to regulate human DC function in a fashion that favors Th1 cell polarization. The effect of those compounds on the maturation and function of human monocyte-derived DC in vitro and their anti-proliferative activities have been examined in HL-60 (human promyelocytic leukemia) cells in a 4,5-dimethylthiazol2-yl-2,5-diphenyltetrazolium bromide (MTT) assay. The effect of uncarinic $\mathrm{C}$ (E configuration at 2'position) was approximately 20 times more potent than that of uncarinic $\mathrm{D}$ ( $Z$ configuration at 2'). These results indicated that the configuration of the 2' double bond greatly effects activity. The results showed that uncarinic acids $\mathrm{C}$ and $\mathrm{D}$ also exhibited antiproliferative activity in HL-60 cells, with $\mathrm{IC}_{50}$ values of 9.8 and $16.8 \mu \mathrm{g} / \mathrm{ml}$ respectively (in comparison with etoposide: $25.0 \mu \mathrm{g} / \mathrm{ml}$ ). It was concluded that, those compounds may prove useful as DC-based vaccines for 
cancer immunotherapy.

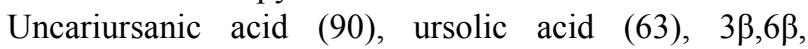
$19 \alpha$-trihydroxy-23-oxo- urs-12-en-28-oic acid (84) and $3 \beta, 6 \beta, 19 \alpha$-trihydroxy-urs- 12 -en-28-oic acid (78) isolated from $U$. macrophylla were evaluated for their in vitro inhibitory potentials against cancer cell lines. Only ursolic acid inhibited the growth of HepG2 and MCF-7 at $\mathrm{IC}_{50}$ values $12.1 \mu \mathrm{g} / \mathrm{mL}$ and $15.1 \mu \mathrm{g} / \mathrm{mL}$, respectively. At an increased inhibitory concentration $\left(\mathrm{IC}_{50}>100 \mu \mathrm{g} / \mathrm{mL}\right.$ ) notwithstanding, the other compounds did not show significant cytotoxicity activities against the tested cancer cell lines [61]. 3 $3,6 \beta, 19 \alpha$-trihydroxy-12-oleanen-28-oic acid (81) also isolated from this plant exhibited a weak antitumor activity, with $\mathrm{IC}_{50}$ values of $78.2 \mu \mathrm{g} / \mathrm{mL}$ and 73.9 $\mu \mathrm{g} / \mathrm{mL}$ against the two cells line in comparison with those of cisplatin $7.5 \mu \mathrm{g} / \mathrm{mL}$ and $8.2 \mu \mathrm{g} / \mathrm{mL}$, respectively [62].

Oleanolic acid (62) and its acetate have been reported as having gastroprotective, anti-inflammatory, antitumour, antioxidant, antidiabetogenic and HIV effects [63]. Ursolic acid stearoyl glucoside has been evaluated for its anticonvulsant and depressant activity on Wistar albinos' rats and Swiss mice. The obtained findings provided evidence of its anticonvulsant and depressant like effect [64].

The ability to act as a scavenger of DPPH radical and the cytotoxicity potential based on brine shrimp assay were confirmed for $\beta$-amyrin acetate (111). Studies conducted by Higuchi et al.[65] reported the growth inhibitory activity against Mycobacterium tuberculosis with MIC of 62.5 $\mu \mathrm{g} / \mathrm{mL}$ for a mixture of an oleanolic (62) and ursolic (63) acids. The high lipophilicity of terpenes is probably the main factor that allows their penetration through the mycobacterial cell wall. Other studies showed that oleanolic acid (MIC of $28.7 \mu \mathrm{g} / \mathrm{mL}$ ) is more active than that ursolic acid (MIC of $41.9 \mu \mathrm{g} / \mathrm{mL}$ ) [66]. The same findings were reported by Cantrel CL et al, 2001 [67] with a MIC of $16 \mu \mathrm{g} / \mathrm{mL}$ for oleanolic acid and $50 \mu \mathrm{g} / \mathrm{mL}$ for ursolic acid.

According to Aquino R et al 1989 [26], five quinovic acid glycosides, 99-104 (Table 3, Figure 3) isolated from $U$. tomentosa and compounds 105-107 isolated from Guettarda platypoda showed an inhibitory effect against vescular stomatitis viral infection. There was no relationship noted between the number of sugar residues and the antiviral activity. The presence of the free C-27 carboxyl group as well as the nature of the sugar moiety seems to be important in inducing activity. Quinovose in $102\left(\mathrm{MIC}_{50}=22.4 \mu \mathrm{g} / \mathrm{ml}\right)$ was more potential than fucose in $103\left(\mathrm{MIC}_{50}=31.4 \mu \mathrm{g} / \mathrm{ml}\right)$ when all the other characters in the structure are the same. The compound 101 containing two free carboxyl groups was notably the most active compound $\left(\mathrm{MIC}_{50}=20.0 \mu \mathrm{g} / \mathrm{ml}\right)$. Almost all these quinovic acid glycosides were inactive against rhinovirus type $1 \mathrm{~B}$ infection in HeLa cells; only 104 and 107, both containing two glucose units and the free C-27 carboxyl group, reduced the viral cytopathic effect by $50 \%$ at a concentration of 30 and $20 \mu \mathrm{g} / \mathrm{ml}$ respectively. The maximum nontoxic concentration for HeLa cells of compound 104 was $60 \mu \mathrm{g} / \mathrm{ml}$ and of compound 107 was $100 \mu \mathrm{g} / \mathrm{ml}$.

\section{Conclusion}

Phenolic compounds isolated from Uncaria species might contribute to their strong antioxidative activity like many other plant phenols. The selective production of some compounds in Uncaria species or in various parts of plant has been assigned. However, much related studies still need to be done in areas of chemotaxonomy of the Uncaria species and subsequent identification of chemical markers for differentiation of Uncaria medicinal preparations. In the search for new compounds, and also in quality control, there is a need to have reliable methodology for the analysis of non-alkaloids. As a group of naturally-occurring non-enzymatic antioxidants, most phenolic components isolated from Uncaria species have potential therapeutic values in the treatment of a wide range of oxidative-stress-mediated pathological conditions such as neurodegenerative, cardiovascular and inflammatory diseases. Full exploitation of the therapeutic potentials of Uncaria species as well as many other plants phenolics awaits the identification of more novel compounds in structural class, elucidation of their structure-activity relationship trends as well as degradation and pharmacokinetics in humans. As active indole alkaloids and phenolic components contribute together to the wide range of pharmacological activities of Uncaria species, it looks more important to study their additive and synergic actions.

\section{Acknowledgment}

The authors thank the Institute of Scientific and Technological Research (IRST-Rwanda), Program of National Natural Science Foundation of China (Grant No.81303182 and No.81173523), National Key Technology R\&D Program (2012ZX09101202 and the Program of the State Key Development Program for Basic Research of China (2012CB723504), for the financial support.

Table 1. Flavonoids isolated from Uncaria species

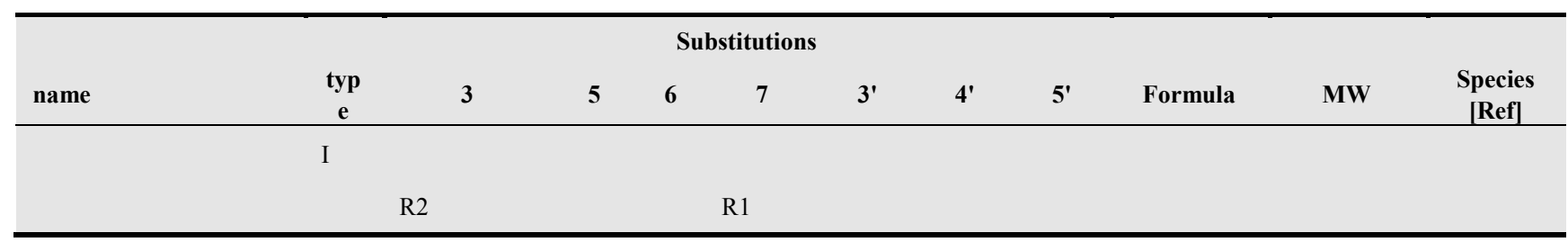




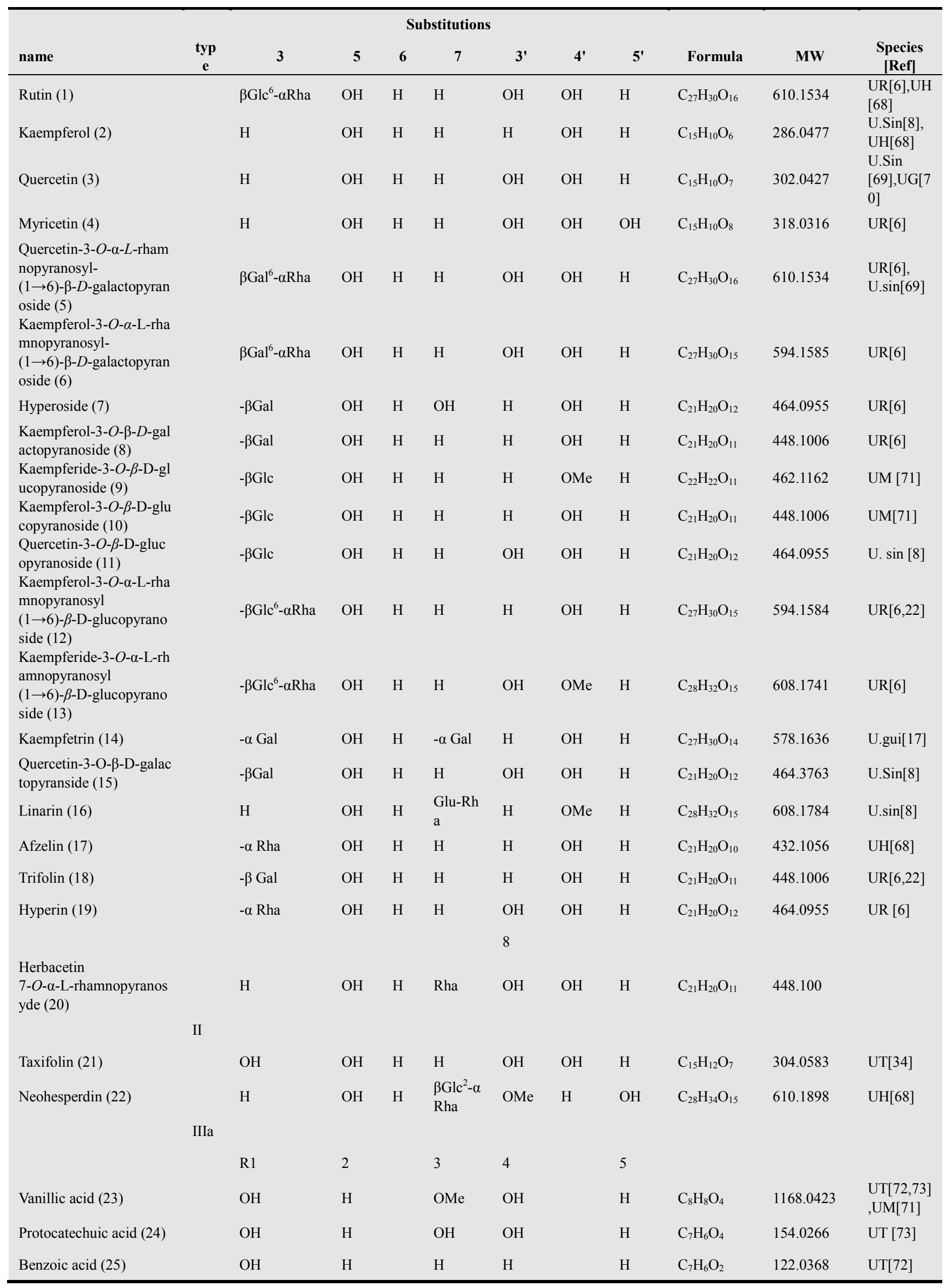




\begin{tabular}{|c|c|c|c|c|c|c|c|c|c|c|c|}
\hline \multirow[b]{2}{*}{ name } & \multicolumn{10}{|c|}{ Substitutions } & \multirow[b]{2}{*}{$\begin{array}{c}\text { Species } \\
\text { [Ref] }\end{array}$} \\
\hline & $\begin{array}{c}\text { typ } \\
\text { e }\end{array}$ & & 5 & 6 & 7 & $3^{\prime}$ & $4^{\prime}$ & $5^{\prime}$ & Formula & MW & \\
\hline & $\mathrm{IIIb}$ & & & & & & & & & & \\
\hline & & $\mathrm{R} 1$ & 2 & & 3 & 4 & & 5 & & & \\
\hline $\begin{array}{l}p \text {-Hydroxybenzoic acid } \\
\text { (26) }\end{array}$ & & $\mathrm{OH}$ & $\mathrm{H}$ & & $\mathrm{H}$ & $\mathrm{OH}$ & & $\mathrm{H}$ & $\mathrm{C}_{7} \mathrm{H}_{6} \mathrm{O}_{3}$ & 138.0317 & $\mathrm{UT}[72,73]$ \\
\hline Gallic acid (27) & & $\mathrm{OH}$ & $\mathrm{H}$ & & $\mathrm{OH}$ & $\mathrm{OH}$ & & $\mathrm{OH}$ & $\mathrm{C}_{7} \mathrm{H}_{6} \mathrm{O}_{5}$ & 170.0215 & $\begin{array}{l}\text { UG[70],U } \\
\text { T[72] } \\
\text { UR }\end{array}$ \\
\hline Syringic acid (28) & & $\mathrm{OH}$ & $\mathrm{H}$ & & $\mathrm{OMe}$ & $\mathrm{OH}$ & & $\mathrm{OMe}$ & $\mathrm{C}_{9} \mathrm{H}_{10} \mathrm{O}_{5}$ & 180.0423 & $\begin{array}{l}{[6], \mathrm{UT}[73} \\
\text { ] }\end{array}$ \\
\hline $\begin{array}{l}\text { Protocatechualdehyde } \\
\text { (29) }\end{array}$ & & $\mathrm{H}$ & $\mathrm{H}$ & & $\mathrm{OH}$ & $\mathrm{OH}$ & & $\mathrm{H}$ & $\mathrm{C}_{7} \mathrm{H}_{6} \mathrm{O}_{3}$ & 138.0317 & UT[73] \\
\hline Syringaldehyde (30) & & $\mathrm{H}$ & $\mathrm{H}$ & & $\mathrm{OMe}$ & $\mathrm{OH}$ & & $\mathrm{OMe}$ & $\mathrm{C}_{9} \mathrm{H}_{10} \mathrm{O}_{4}$ & 182.0579 & UT [73] \\
\hline $\begin{array}{l}p \text {-Hydroxybenzaldehyde } \\
\text { (31) }\end{array}$ & & $\mathrm{H}$ & $\mathrm{H}$ & & $\mathrm{H}$ & $\mathrm{OH}$ & & $\mathrm{H}$ & $\mathrm{C}_{7} \mathrm{H}_{6} \mathrm{O}_{2}$ & 122.0368 & UT [73] \\
\hline Vanillin & & $\mathrm{H}$ & $\mathrm{H}$ & & $\mathrm{OMe}$ & $\mathrm{OH}$ & & $\mathrm{H}$ & $\mathrm{C}_{8} \mathrm{H}_{8} \mathrm{O}_{3}$ & 152.0473 & UT[73] \\
\hline & IV & & & & & & & & & & \\
\hline$p$-Coumaric acid (32) & & * & $\mathrm{H}$ & & $\mathrm{H}$ & $\mathrm{OH}$ & & $\mathrm{H}$ & $\mathrm{C}_{9} \mathrm{H}_{8} \mathrm{O}_{3}$ & 164.0473 & UT[73] \\
\hline$O$-Coumaric acid (33) & & $*$ & $\mathrm{OH}$ & & $\mathrm{H}$ & $\mathrm{H}$ & & $\mathrm{H}$ & $\mathrm{C}_{9} \mathrm{H}_{8} \mathrm{O}_{3}$ & 164.0473 & UT[73] \\
\hline$m$-Coumaric acid (34) & & $*$ & $\mathrm{H}$ & & $\mathrm{OH}$ & $\mathrm{H}$ & & $\mathrm{H}$ & $\mathrm{C}_{9} \mathrm{H}_{8} \mathrm{O}_{3}$ & 164.0473 & UT[73] \\
\hline Cinnamic acid (35) & & $*$ & $\mathrm{H}$ & & $\mathrm{H}$ & $\mathrm{H}$ & & $\mathrm{H}$ & $\mathrm{C}_{9} \mathrm{H}_{8} \mathrm{O}_{2}$ & 148.0524 & UT[73] \\
\hline Ferulic acid (36) & & * & $\mathrm{H}$ & & $\mathrm{OMe}$ & $\mathrm{OH}$ & & $\mathrm{H}$ & $\mathrm{C}_{10} \mathrm{H}_{10} \mathrm{O}_{4}$ & 194.0579 & UT[73] \\
\hline Sinapic acid (37) & & * & $\mathrm{H}$ & & $\mathrm{OMe}$ & $\mathrm{OH}$ & & $\mathrm{OMe}$ & $\mathrm{C}_{11} \mathrm{H}_{12} \mathrm{O}_{5}$ & 224.0685 & UT[73] \\
\hline Caffeic acid (38) & & * & $\mathrm{H}$ & & $\mathrm{OH}$ & $\mathrm{OH}$ & & $\mathrm{H}$ & $\mathrm{C}_{9} \mathrm{H}_{8} \mathrm{O}_{4}$ & 180.0423 & UR [6] \\
\hline Chlogenic acid (39) & & * & - & - & - & - & & - & $\mathrm{C}_{16} \mathrm{H}_{18} \mathrm{O}_{9}$ & 354.0951 & $\begin{array}{l}\mathrm{UH}[68], \mathrm{U} \\
\mathrm{T}[74]\end{array}$ \\
\hline Rosmarinic acid (40) & & $*$ & - & - & - & - & & - & $\mathrm{C}_{18} \mathrm{H}_{16} \mathrm{O}_{8}$ & 360.0845 & $\begin{array}{l}\text { UT[72], } \\
\text { UR[75] }\end{array}$ \\
\hline Rosimarinate (41) & & * & - & - & - & - & & - & $\mathrm{C}_{19} \mathrm{H}_{18} \mathrm{O}_{8}$ & 374.1002 & $\begin{array}{l}\text { UT[72], } \\
\text { UR[75] }\end{array}$ \\
\hline
\end{tabular}

Table 2. Flavan-3-ols and their dimmers

\begin{tabular}{lllll}
\hline name & type & formula & MW & Species [Ref] \\
\hline Gambiriin A1 (42) & IV & $\mathrm{C}_{30} \mathrm{H}_{28} \mathrm{O}_{12}$ & 580.1581 & UG[76] \\
Gambiriin A2 (43) & IV & $\mathrm{C}_{30} \mathrm{H}_{28} \mathrm{O}_{12}$ & 580.1581 & UG[76] \\
Gambiriin A3 (44) & IV & $\mathrm{C}_{30} \mathrm{H}_{28} \mathrm{O}_{12}$ & 580.1581 & UG [28] \\
Gambiriin B1 (45) & IV & $\mathrm{C}_{30} \mathrm{H}_{26} \mathrm{O}_{11}$ & 562.1475 & UG[76] \\
Gambiriin B2 (46) & IV & $\mathrm{C}_{30} \mathrm{H}_{26} \mathrm{O}_{11}$ & 562.1475 & UG [76] \\
Gambiriin B3 (47) & IV & $\mathrm{C}_{30} \mathrm{H}_{26} \mathrm{O}_{11}$ & 562.1475 & UG [76] \\
Gambiriin C (48) & IV & $\mathrm{C}_{30} \mathrm{H}_{26} \mathrm{O}_{11}$ & 562.1475 & UG[76] \\
Procyanidin B1(49) & IV & $\mathrm{C}_{30} \mathrm{H}_{26} \mathrm{O}_{12}$ & 578.1424 & UG [76] \\
Procyanidin B2 (50) & IV & $\mathrm{C}_{30} \mathrm{H}_{26} \mathrm{O}_{12}$ & 578.1424 & UR [6] \\
Procyanidin B3 (51) & IV & $\mathrm{C}_{30} \mathrm{H}_{26} \mathrm{O}_{12}$ & 578.1424 & UG [76] \\
Cinchonain Ia (52) & IV & $\mathrm{C}_{24} \mathrm{H}_{20} \mathrm{O}_{9}$ & 452.1107 & UG[76], UT[77] \\
Cinchonain Ib (53) & IV & $\mathrm{C}_{39} \mathrm{H}_{32} \mathrm{O}_{15}$ & 740.1741 & UG [28], UT[77] \\
(+)-Catechin (54) & IV & $\mathrm{C}_{15} \mathrm{H}_{14} \mathrm{O}_{6}$ & 290.0790 & UG [76] \\
(-)-Catechin (55) & IV & $\mathrm{C}_{15} \mathrm{H}_{14} \mathrm{O}_{6}$ & 290.0790 & UG [28] \\
(+)-Epicatechin (56) & IV & $\mathrm{C}_{15} \mathrm{H}_{14} \mathrm{O}_{6}$ & 290.0790 & UG [76], UR [6],UE[78] \\
(-)-Epicatechin (57) & IV & $\mathrm{C}_{15} \mathrm{H}_{14} \mathrm{O}_{6}$ & 290.0790 & UG[70], UE [78] \\
Epigallocatechin (58) & IV & $\mathrm{C}_{15} \mathrm{H}_{14} \mathrm{O}_{7}$ & 306.0740 & UG[70] \\
Epigallocatechin gallate (59) & IV & $\mathrm{C}_{22} \mathrm{H}_{18} \mathrm{O}_{11}$ & 458.0849 & UG[70] \\
Gambirfavan D4 (60) & IV & $\mathrm{C}_{30} \mathrm{H}_{28} \mathrm{O}_{12}$ & 580.1581 & UG[79] \\
Gambirfavan D5 (61) & IV & $\mathrm{C}_{30} \mathrm{H}_{28} \mathrm{O}_{12}$ & 580.1581 & UG[79] \\
\hline
\end{tabular}


Table 3. Pentacyclic triterpenoids and triterpenes saponins

\begin{tabular}{|c|c|c|c|c|}
\hline name & type & formula & MW & Species [Ref] \\
\hline Oleanolic acid (62) & $\mathrm{V}$ & $\mathrm{C}_{30} \mathrm{H}_{48} \mathrm{O}_{3}$ & 456.36 & $\mathrm{UT}[19]$ \\
\hline Ursolic acid (63) & $\mathrm{V}$ & $\mathrm{C}_{30} \mathrm{H}_{48} \mathrm{O}_{3}$ & 456.36 & $\mathrm{UH}[68], \mathrm{UM}[80]$ \\
\hline Uncaric acid (64) & $\mathrm{V}$ & $\mathrm{C}_{30} \mathrm{H}_{48} \mathrm{O}_{3}$ & 456.36 & U.th [81] \\
\hline Diketouncaric acid (65) & $\mathrm{V}$ & $\mathrm{C}_{30} \mathrm{H}_{44} \mathrm{O}_{5}$ & 484.31 & U.th [81] \\
\hline Diacetyluncaric acid (66) & $\mathrm{V}$ & $\mathrm{C}_{34} \mathrm{H}_{52} \mathrm{O}_{7}$ & 572.37 & U.th[81] \\
\hline 3-O- $\beta$-D-glucuronopyranosyl-ursolic acid (67) & $\mathrm{V}$ & $\mathrm{C}_{36} \mathrm{H}_{56} \mathrm{O}_{9}$ & 632.39 & $\mathrm{UM}[80]$ \\
\hline Uncarinic acid A (68) & $\mathrm{V}$ & $\mathrm{C}_{40} \mathrm{H}_{56} \mathrm{O}_{7}$ & 648.40 & UR [13] \\
\hline Uncarinic acid B (69) & $\mathrm{V}$ & $\mathrm{C}_{40} \mathrm{H}_{56} \mathrm{O}_{7}$ & 648.40 & UR [13] \\
\hline Uncarinic acid C (70) & V & $\mathrm{C}_{40} \mathrm{H}_{56} \mathrm{O}_{7}$ & 648.40 & UR [13] \\
\hline Uncarinic acid D (71) & $\mathrm{V}$ & $\mathrm{C}_{40} \mathrm{H}_{56} \mathrm{O}_{7}$ & 648.40 & UR [13] \\
\hline Uncarinic acid E (72) & $\mathrm{V}$ & $\mathrm{C}_{40} \mathrm{H}_{56} \mathrm{O}_{7}$ & 648.40 & UR [13] \\
\hline $3 \beta$-Hydroxy-27-p-(Z)-coumaroyloxyolean-12-en-28-oic acid (73) & $\mathrm{V}$ & $\mathrm{C}_{39} \mathrm{H}_{54} \mathrm{O}_{6}$ & 618.39 & UR $[6,13,59]$ \\
\hline 3ß-Hydroxy-27-p- $(E)$-coumaroyloxyurs-12-en-28-oic acid (74) & $\mathrm{V}$ & $\mathrm{C}_{39} \mathrm{H}_{54} \mathrm{O}_{6}$ & 618.39 & UR [13] \\
\hline $3 \beta$-Hydroxy-27-p-(Z)-coumaroyloxyurs-12-en-28-oic acid (75) & $\mathrm{V}$ & $\mathrm{C}_{39} \mathrm{H}_{54} \mathrm{O}_{6}$ & 618.39 & UR [13] \\
\hline Ursonic acid (6ß-hydroxyursolic acid) (76) & V & $\mathrm{C}_{30} \mathrm{H}_{4} \mathrm{O}_{4}$ & 472.35 & UM [62] \\
\hline $3 \beta, 6 \beta, 19 \alpha$-Trihydroxy-urs-12-en-28-oic acid (77) & $\mathrm{V}$ & $\mathrm{C}_{30} \mathrm{H}_{48} \mathrm{O}_{5}$ & 488.35 & UR [6], UM[61] \\
\hline $3 \beta, 6 \beta, 23$-Trihydroxyursa-12-en-28-oic acid(78) & $\mathrm{V}$ & $\mathrm{C}_{30} \mathrm{H}_{48} \mathrm{O}_{5}$ & 488.35 & UR [6] \\
\hline 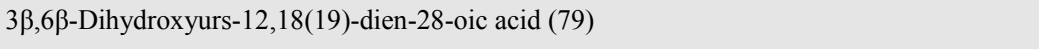 & V & $\mathrm{C}_{30} \mathrm{H}_{46} \mathrm{O}_{4}$ & 470.33 & UM [61] \\
\hline $3 \beta$-Hydroxyurs-5(6),12,18(19)-trien-28-oic acid (80) & V & $\mathrm{C}_{30} \mathrm{H}_{44} \mathrm{O}_{3}$ & 452.32 & $\mathrm{UM}[62]$ \\
\hline 3ß,23-Dihydroxyolean-12-en-28-oic acid (81) & $\mathrm{V}$ & $\mathrm{C}_{30} \mathrm{H}_{48} \mathrm{O}_{4}$ & 472.35 & $\mathrm{UM}[62]$ \\
\hline 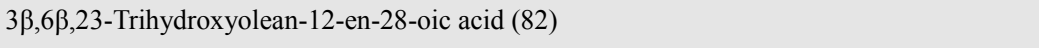 & V & $\mathrm{C}_{30} \mathrm{H}_{48} \mathrm{O}_{5}$ & 488.35 & $\mathrm{UM}[62]$ \\
\hline Uncargenin D (83) & V & $\mathrm{C}_{30} \mathrm{H}_{46} \mathrm{O}_{4}$ & 470.33 & UR[82] \\
\hline $3 \beta, 6 \beta, 19 \alpha$-Trihydroxy-23-oxo-urs-12-en-28-oic acid (84) & V & $\mathrm{C}_{30} \mathrm{H}_{46} \mathrm{O}_{6}$ & 502.32 & UM [61] \\
\hline 23 -nor-24-esomethylene-3 $\beta, 6 \beta, 19 \alpha$-trihydroxyurs-12-en-28-oic acid ( 85 ) & $\mathrm{V}$ & $\mathrm{C}_{29} \mathrm{H}_{44} \mathrm{O}_{5}$ & 472.31 & $\mathrm{UT}[20]$ \\
\hline 3-oxo-6 $\beta, 19 \alpha$-Dihydroxyurs-12-en-28-oic-acid (86) & $\mathrm{V}$ & $\mathrm{C}_{30} \mathrm{H}_{46} \mathrm{O}_{5}$ & 486.33 & $\mathrm{UT}[20]$ \\
\hline 3ß-Hydroxyurs-12-en-27,28-dioic acid (87) & V & $\mathrm{C}_{30} \mathrm{H}_{46} \mathrm{O}_{5}$ & 486.33 & $\mathrm{UM}[80]$ \\
\hline 7-oxo-3 $\beta$-hydroxyurs-12-en-27,28-dioic acid (88) & $\mathrm{V}$ & $\mathrm{C}_{30} \mathrm{H}_{44} \mathrm{O}_{6}$ & 500.67 & $\mathrm{UT}[20]$ \\
\hline 3 $\beta$-methoxy-16 $\alpha$-hydroxyursa-12,19(29)-dien-27,28-dioic acid (89) & $\mathrm{V}$ & $\mathrm{C}_{31} \mathrm{H}_{46} \mathrm{O}_{6}$ & 514.71 & $\mathrm{UT}[20]$ \\
\hline Uncariursanic acid (90) & $\mathrm{V}$ & $\mathrm{C}_{31} \mathrm{H}_{48} \mathrm{O}_{7}$ & 532.34 & UM [61] \\
\hline $3 \beta, 6 \beta, 19 \alpha$-Trihydroxy-12-oleanen-28-oic acid (91) & $\mathrm{V}$ & $\mathrm{C}_{31} \mathrm{H}_{48} \mathrm{O}_{5}$ & 488.35 & $\mathrm{UM}[62]$ \\
\hline (3ß)-3-Hydroxy-27-noroleano-13(28)-lactone (92) & V & $\mathrm{C}_{29} \mathrm{H}_{46} \mathrm{O}_{3}$ & 442.34 & $\mathrm{UH}[83]$ \\
\hline (22 $\alpha$ )-22-Hydroxy-3-oxours-12-ene-27,28-dioic acid (93) & $\mathrm{V}$ & $\mathrm{C}_{30} \mathrm{H}_{52} \mathrm{O}_{6}$ & 532.37 & $\mathrm{UH}[83]$ \\
\hline Quinovic acid (94) & $\mathrm{V}$ & $\mathrm{C}_{32} \mathrm{H}_{54} \mathrm{O}_{6}$ & 534.39 & $\mathrm{UH}[83]$ \\
\hline (3ß)-3-( $\beta$-D-Glucopyranosyloxy)-12-oxopyroqu-inovic acid $\beta$-D glucopyranosyl ester (95) & V & $\mathrm{C}_{41} \mathrm{H}_{64} \mathrm{O}_{14}$ & 780.42 & $\mathrm{UH}[83]$ \\
\hline Pyrocincholic acid (96) & V & $\mathrm{C}_{29} \mathrm{H}_{46} \mathrm{O}_{3}$ & 442.34 & $\mathrm{UH}[83]$ \\
\hline Pyrocincholic acid ethyl ester (97) & $\mathrm{V}$ & $\mathrm{C}_{31} \mathrm{H}_{50} \mathrm{O}_{3}$ & 470.37 & UH $[83]$ \\
\hline (3ß)-3-( $\beta$-D-Quinovopyranosyloxy)pyro-cincholic acid $\beta$-D- glucopyranosyl ester (98) & $\mathrm{V}$ & $\mathrm{C}_{41} \mathrm{H}_{66} \mathrm{O}_{12}$ & 750.45 & $\mathrm{UH}[83]$ \\
\hline $\begin{array}{l}\text { Quinovic acid-3 } \beta-O-[\beta-D \text {-glucopyranosyl- }(1 \rightarrow 3)-\beta-D-\text { fucopyranosyl]- }(27 \rightarrow 1)-\beta-D- \\
\text { glucopyranosyl ester }(99)\end{array}$ & $\mathrm{V}$ & $\mathrm{C}_{49} \mathrm{H}_{76} \mathrm{O}_{19}$ & 956.49 & UT[25],UG[84] \\
\hline $\begin{array}{l}\text { Quinovic acid-3 } \beta \text {-O-[ } \beta \text {-D-glucopyranosyl- }(1 \rightarrow 3)-\beta-D-\quad \text { fucopyranosyl]- } \quad(28 \rightarrow 1)-\beta \text {-D- } \\
\text { glucopyranosyl ester }(100)\end{array}$ & $\mathrm{V}$ & $\mathrm{C}_{48} \mathrm{H}_{79} \mathrm{O}_{19}$ & 956.49 & UT[25],UG[84] \\
\hline Quinovic acid-3 $\beta$-O-[ $\beta$-D-glucopyranosyl-( $1 \rightarrow 3)$ - $\beta$-D- fucopyranoside] (101) & V & $\mathrm{C}_{42} \mathrm{H}_{66} \mathrm{O}_{14}$ & 794.44 & UT[25],UG[84] \\
\hline Quinovic acid-3 $\beta$-O-( $\beta$-D-quinovopyranosyl)- $(28 \rightarrow 1)-\beta$-D- glucopyranosyl ester $(102)$ & V & $\mathrm{C}_{42} \mathrm{H}_{66} \mathrm{O}_{14}$ & 794.44 & UT[26] \\
\hline Quinovic acid-3 $\beta$-O-( $\beta$-D-fucopyranosyl)- $(28 \rightarrow 1)-\beta$-D- glucopyranosyl ester $(103)$ & V & $\mathrm{C}_{42} \mathrm{H}_{66} \mathrm{O}_{14}$ & 794.44 & UT[26] \\
\hline 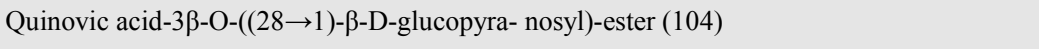 & $\mathrm{V}$ & $\mathrm{C}_{42} \mathrm{H}_{66} \mathrm{O}_{15}$ & 810.44 & $\mathrm{UT}[26]$ \\
\hline Quinovic acid-3 $\beta$-O-( $\beta$-D-quinovopyranosyl)- $(27 \rightarrow 1)$ - $\beta$-D- glucopyranosyl ester $(108)$ & $\mathrm{V}$ & $\mathrm{C}_{43} \mathrm{H}_{68} \mathrm{O}_{13}$ & 792.46 & UT[19], UG[84] \\
\hline $3 \beta, 6 \beta, 19 \alpha$-Trihydroxyurs-12-ene-23,28-dimethyloate (109) & V & $\mathrm{C}_{32} \mathrm{H}_{50} \mathrm{O}_{7}$ & 546.73 & UT[19] \\
\hline Quinovic acid-3- $\beta$-O-( $\beta$-D-fucopyranosyl)- $(27 \rightarrow 1)-\beta$-D- glucopyranosyl ester $(110)$ & $\mathrm{V}$ & $\mathrm{C}_{42} \mathrm{H}_{66} \mathrm{O}_{14}$ & 794.44 & UT[19], UG[84] \\
\hline$\beta$-Amyrin acetate (111) & V & $\mathrm{C}_{32} \mathrm{H}_{52} \mathrm{O}_{2}$ & 468.39 & $\mathrm{UM}[80]$ \\
\hline Tomentosides A (112) & VI & $\mathrm{C}_{47} \mathrm{H}_{76} \mathrm{O}_{17}$ & 913.12 & $\mathrm{UT}[85]$ \\
\hline Tomentosides B (113) & VI & $\mathrm{C}_{47} \mathrm{H}_{76} \mathrm{O}_{17}$ & 913.12 & UT[85] \\
\hline
\end{tabular}


Table 4. Steroids, coumarins and lignans

\begin{tabular}{|c|c|c|c|c|}
\hline name & type & formula & MW & Species [Ref] \\
\hline$\beta$-Sitosterol (114) & VII & $\mathrm{C}_{29} \mathrm{H}_{50} \mathrm{O}$ & 414.38 & UT[18], UR [6] \\
\hline$\beta$-Daucosterol (115) & VII & $\mathrm{C}_{35} \mathrm{H}_{60} \mathrm{O}_{6}$ & 576.43 & $\mathrm{UT}[7], \mathrm{UR}[6], \mathrm{UH}[68], \mathrm{UM}[80]$ \\
\hline Campesterol (116) & VII & $\mathrm{C}_{29} \mathrm{H}_{48} \mathrm{O}$ & 412.37 & $\mathrm{UT}[7,18]$ \\
\hline Stigmasterol (117) & VII & $\mathrm{C}_{29} \mathrm{H}_{48} \mathrm{O}$ & 412.37 & UT [18] \\
\hline Scopoletin (118) & VIII & $\mathrm{C}_{10} \mathrm{H}_{8} \mathrm{O}_{4}$ & 192.04 & \\
\hline Umbelliferone (119) & VIII & $\mathrm{C}_{9} \mathrm{H}_{6} \mathrm{O}_{3}$ & 162.03 & $\mathrm{UH}[68]$ \\
\hline$(2 \mathrm{R}, 3 \mathrm{R}, 4 \mathrm{~S})$-Lyoniresinol-3 $\alpha-O-\beta$-D-glucopyranoside (120) & VIII & $\mathrm{C}_{28} \mathrm{H}_{38} \mathrm{O}_{13}$ & 582.23 & U.sin [5] \\
\hline (2S,3S,4R)-Lyoniresinol-3 $\alpha$-O- $\beta$-D-glucopyranoside (121) & IX & $\mathrm{C}_{28} \mathrm{H}_{38} \mathrm{O}_{13}$ & 582.23 & U.sin [5] \\
\hline$(2 \mathrm{~S}, 3 \mathrm{R}, 4 \mathrm{~S})$-Lyoniresinol-3 $\alpha-O-\beta-\mathrm{D}$-glucopyranoside(122) & $\mathrm{IX}$ & $\mathrm{C}_{28} \mathrm{H}_{38} \mathrm{O}_{13}$ & 582.23 & U.sin [5] \\
\hline$(2 \mathrm{R}, 3 \mathrm{~S}, 4 \mathrm{R})$-Lyoniresinol-3 $\alpha-O-\beta$-D-glucopyranoside (123) & IX & $\mathrm{C}_{28} \mathrm{H}_{38} \mathrm{O}_{13}$ & 582.23 & U.sin [5] \\
\hline
\end{tabular}

Key to name of Uncaria species; UT: U. tomentosa; UR: U.rhynchophylla; UM: U.macrophylla; UH: U.hirsuta; Usin: U. sinensis; UG: U. gambir; U.th; U. thwaitesii, UE: U.elliptica; Ugui: U.guianensis

MW: molecular weight; *: Unconsidered; - : Absence<smiles>[R6]Oc1cc(O)c2c(=O)c(-c3cc[14c](Oc4ccc5c(c4)OC(c4ccccc4)CC5=O)cc3)c([R20])cc-2o1</smiles>

Flavone (I)

Flavanone (II)<smiles>CCOC(=O)c1ccccc1</smiles>

IIla<smiles>[R]C(=O)/C=C/[I+]c1ccccc1</smiles>

IIIlb<smiles>OC1Cc2ccccc2O[C@H]1c1ccccc1</smiles>

Simple phenolic compounds

Flavanols (IV)<smiles>[R]OC(=O)C(=O)OC1CC2(O)CC(O)C1C(O)C(C(=O)OC(C)(C)C)C2O</smiles>

Figure 1. Main structures skeletons of flavonoids constituents<smiles>Oc1cc(O)c(C[C@@H](O)[C@H](c2ccc(O)c(O)c2)c2c(O)cc(O)c3c2O[C@H](c2ccc(O)c(O)c2)C(O)C3)c(O)c1</smiles>

Gambirin A1(42)<smiles>Oc1cc(O)c(C[C@@H](O)[C@H](c2ccc(O)c(O)c2)c2c(O)cc(O)c3c2OC(c2ccc(O)c(O)c2)C(O)C3)c(O)c1</smiles>

Gambiriin A2 (43) 
<smiles>Oc1cc(O)c(CC(O)C(c2ccc(O)c(O)c2)c2c(O)cc3c(c2O)CC(O)[C@@H](c2ccc(O)c(O)c2)O3)c(O)c1</smiles>

Gambiriin B2 (46)

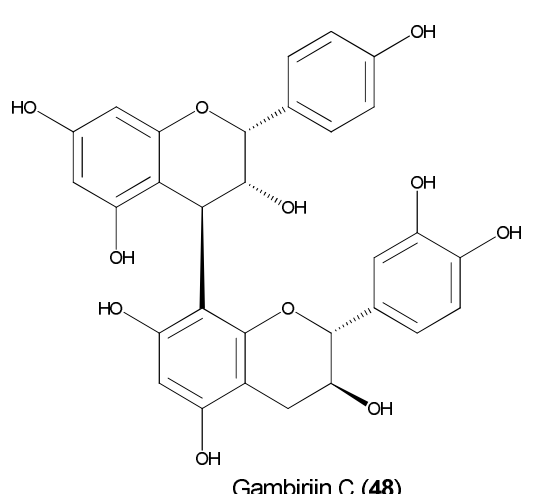

Gambiriin C (48)<smiles>Oc1cc(O)c(C[C@@H]2Oc3cc(O)c4c(c3[C@@H]2c2ccc(O)c(O)c2)O[C@H](c2ccc(O)c(O)c2)C(O)C4)c(O)c1</smiles>

Gambirin B1(45)

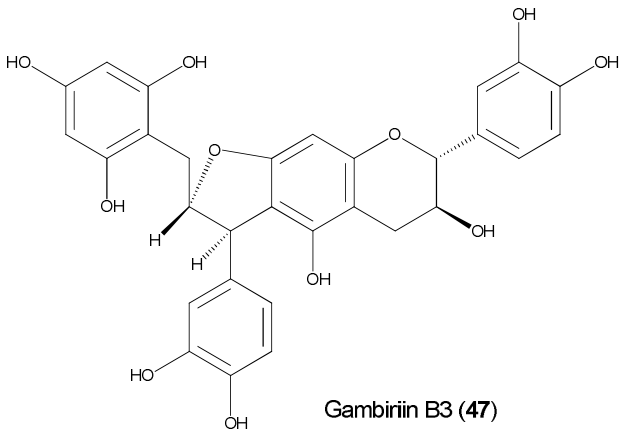<smiles>CCCOc1cc(O)c(C2c3c(O)cc(O)cc3O[C@H](c3ccc(O)c(O)c3)[C@H]2O)c2c1CC(O)[C@H](c1ccc(O)c(O)c1)O2</smiles><smiles>Oc1cc(O)c2c(c1)O[C@H](c1ccc(O)c(O)c1)[C@H](O)[C@H]2c1c(O)cc(O)c2c1O[C@H](c1ccc(O)c(O)c1)[C@H](O)C2</smiles>

Procyanidin B2 (50)<smiles>Cc1ccc([C@@H]2Oc3c(c(O)cc(O)c3[C@@H]3c4c(O)cc(O)cc4O[C@H](c4ccc(O)c(O)c4)C3O)CC2O)cc1O</smiles>

Procyanidin B3 (51)<smiles></smiles>

Cinchonain la (52) 
<smiles>O=C1C[C@H](c2ccc(O)c(O)c2)c2c(cc(O)c3c2OC(c2ccc(O)c(O)c2)[C@H](O)C3c2c(O)cc(O)c3c2OC(c2ccc(O)c(O)c2)[C@H](O)C3)O1</smiles>

Cinchonain Ib (53)<smiles>Oc1ccc([C@@H]2Oc3cc(I)cc(O)c3CC2O)cc1O</smiles>

(+)-Catechin (54)<smiles>Oc1cc(O)c2c(c1)OC(c1ccc(O)c(O)c1)[C@H](O)C2</smiles>

(-)-Catechin (55)<smiles>Oc1cc(O)c2c(c1)O[C@H](c1ccc(O)c(O)c1)[C@H](O)C2</smiles>

(-)-Epicatechin (57)<smiles>Oc1cc(O)c2c(c1)O[C@H](c1cc(O)c(O)c(O)c1)C(O)C2</smiles>

Epigallocatechin (58)

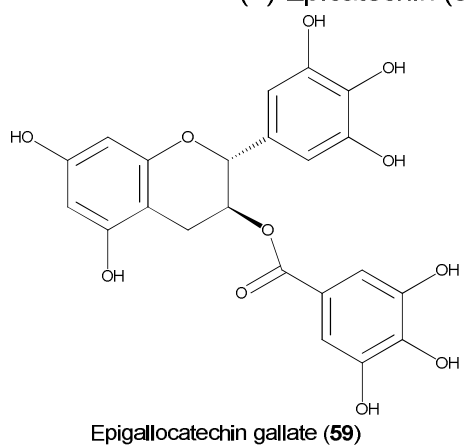

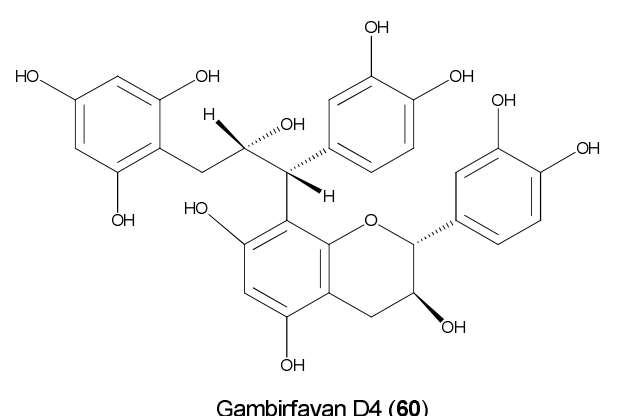

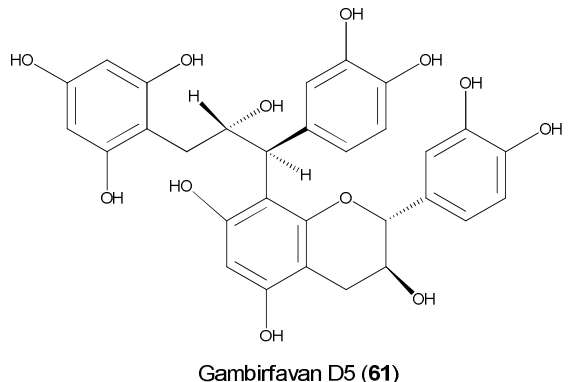

Figure 2. Flavan-3-ols and their dimmers<smiles>CC1(C)CCC2(C(=O)O)CC[C@H]3C(=CCC4C5(C)CCC(O)C(C)(C)C5CCC43C)C2C1</smiles>

Oleanolic acid (62)

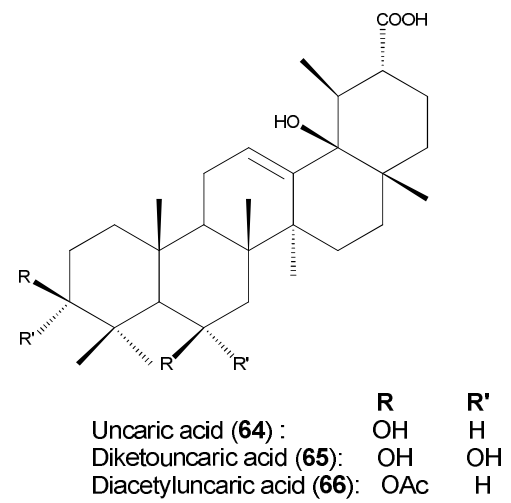


<smiles>CC1CCC2(C(=O)O)CCC3C(=CCC4C3(C)CCC3C(C)(C)C(OC5OC(C(=O)O)[C@@H](O)[C@H](O)[C@H]5O)CCC34C)C2C1C</smiles>

67

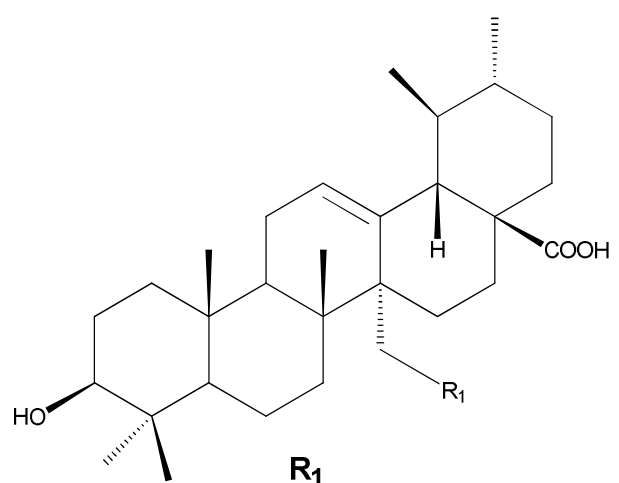

70: E-feruloyl

71: Z-feruloyl

74: p-E-coumaroyl

75: p-Z-coumaroyl
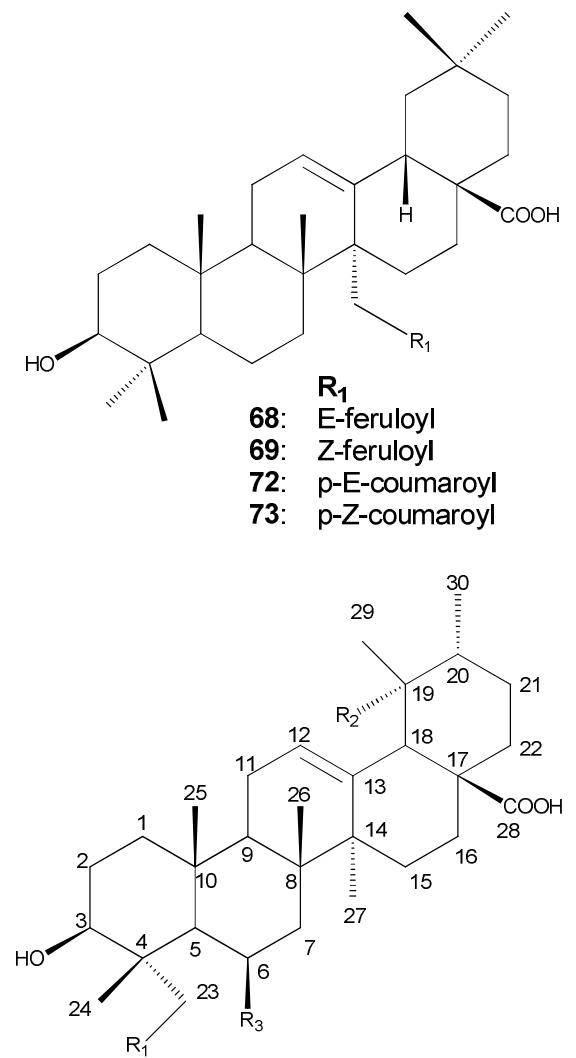

$\begin{array}{llll} & \mathbf{R}_{\mathbf{1}} & \mathbf{R}_{\mathbf{2}} & \mathbf{R}_{\mathbf{3}} \\ \text { 76: } & \mathrm{H} & \mathrm{H} & \beta-\mathrm{OH} \\ \text { 77: } & \mathrm{H} & \mathrm{OH} & \beta-\mathrm{OH} \\ \text { 78: } & \mathrm{OH} & \mathrm{H} & \beta-\mathrm{OH} \\ \text { 63: } & \mathrm{H} & \mathrm{H} & \mathrm{H}\end{array}$<smiles>CC1=C2C3=CCC4C(C)(CC(O)(O)C5C(C)(C)C(O)CCC54C)C3CCC2(O[O+])CC[C@@H]1C</smiles>

79<smiles>CC1(C)CCC2(C(=O)O)CC[C@]3(C)C(=CCC4C5(C)CC[C@H](O)C(C)(CO)C5C(O)C[C@]43C)C2C1</smiles><smiles>CC1=C2C3=CCC4C5(C)CCC(O)C(C)(C)C5=CCC4(C)C3CCC2(C(=O)O)CC[C@H]1C</smiles>

80

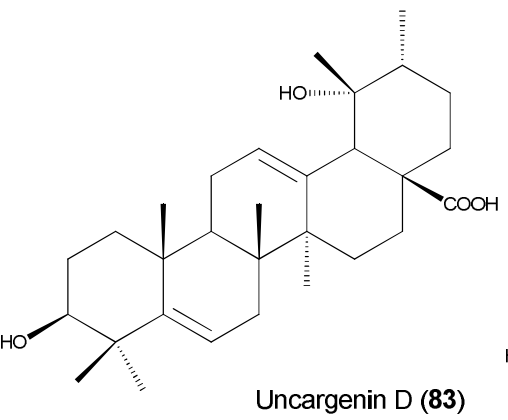

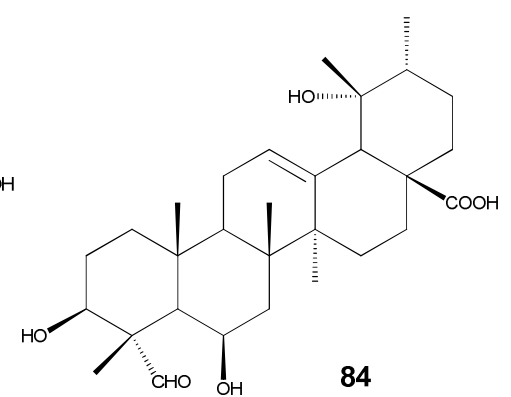



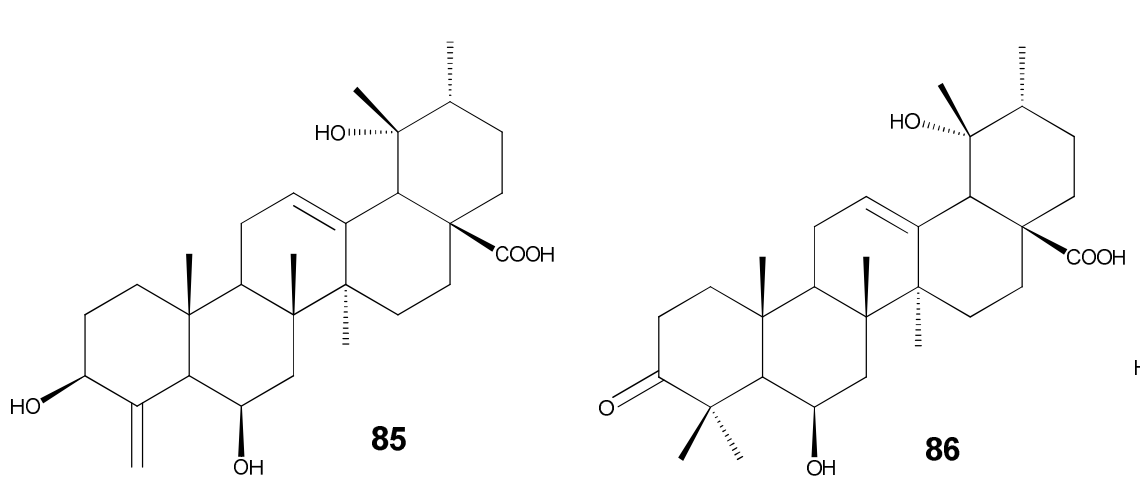<smiles>CC1CCC2(C(=O)O)CC[C@]3(C(=O)O)C(=CCC4C5(C)CCC(O)C(C)(C)C5CCC43C)C2C1C</smiles><smiles>CC1CCCC2(O)CCC3(O)C(=CCC4C5(C)CCC(O)C(C)(C)C5CC(=O)C43C)C12</smiles><smiles>C=C1C2C3=CCC4[C@@]5(C)CC[C@H](O)C(C)(C)[C@@H]5CC[C@@]4(C)[C@]3(C(=O)O)C[C@H](O)C2(C(=O)O)CC[C@H]1C</smiles>

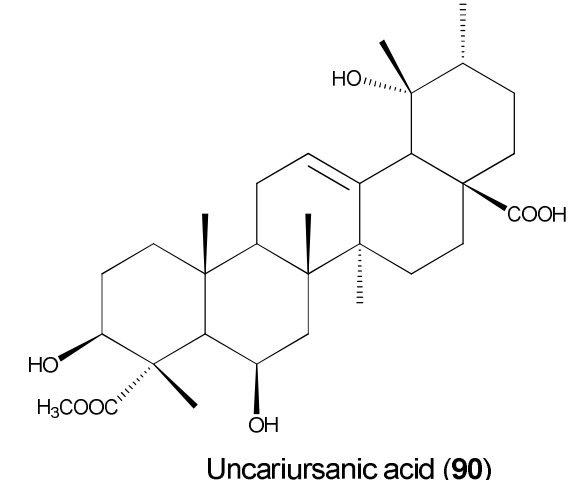<smiles>CC1(C)C(O)CC[C@@]2(C)C1C(O)C[C@]1(C)C2CC=C2C3[C@H](O)C(C)(C)CCC3(C(=O)O)CC[C@@H]21</smiles>

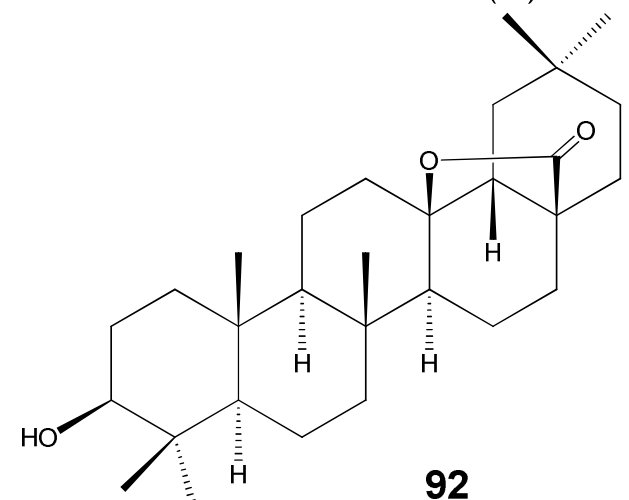

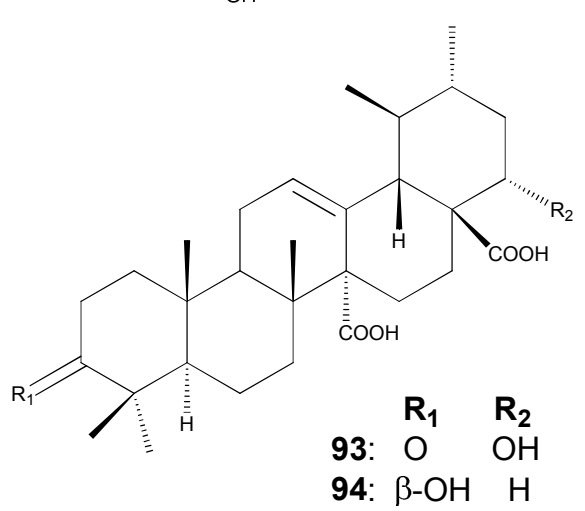
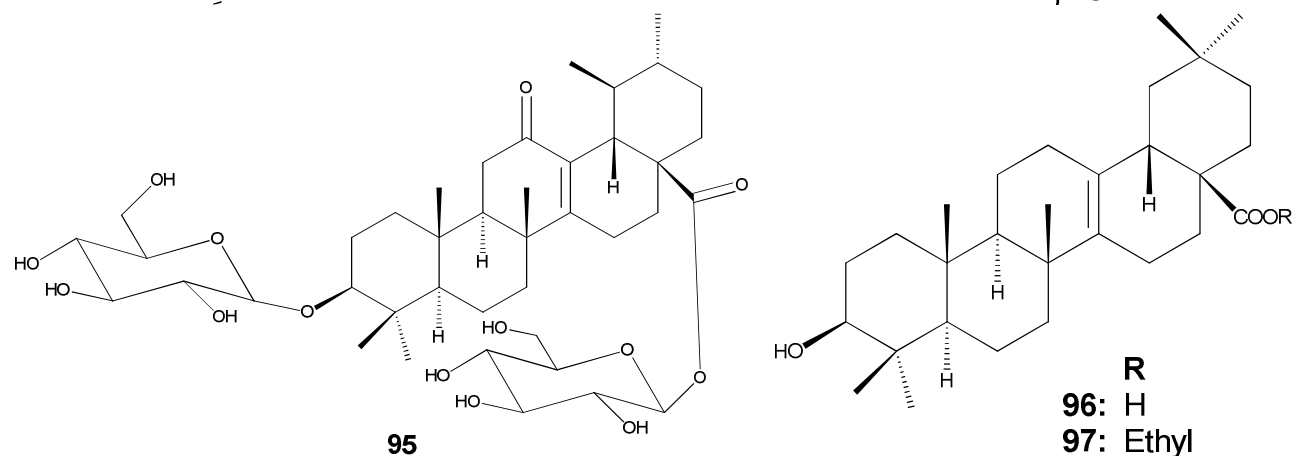


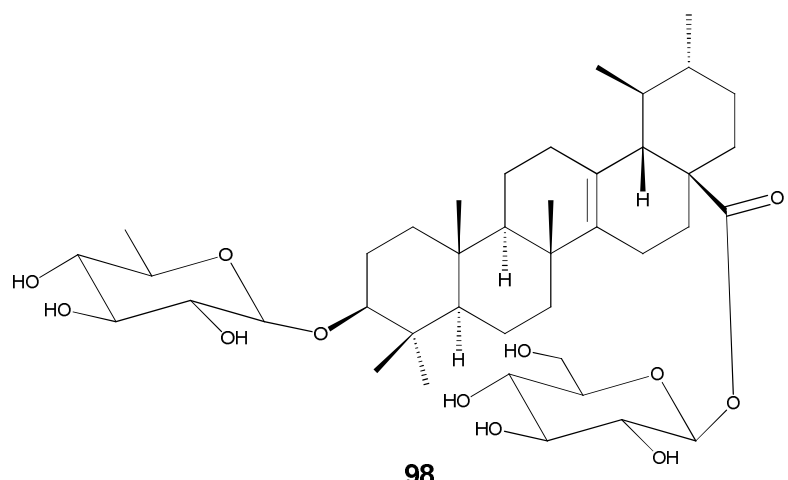

98

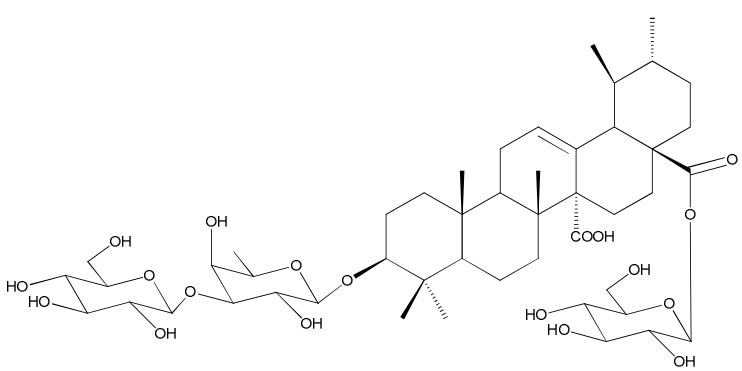

100

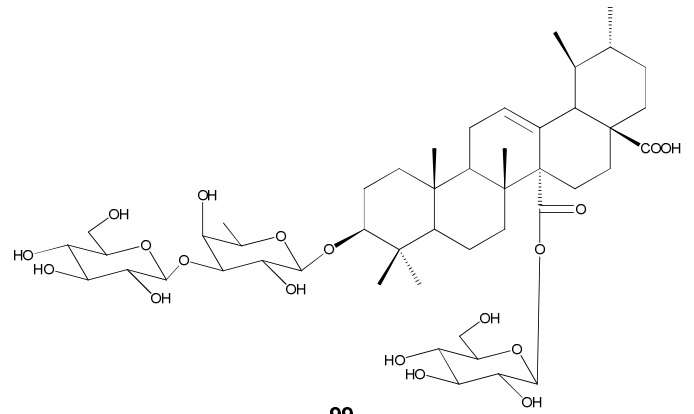

99

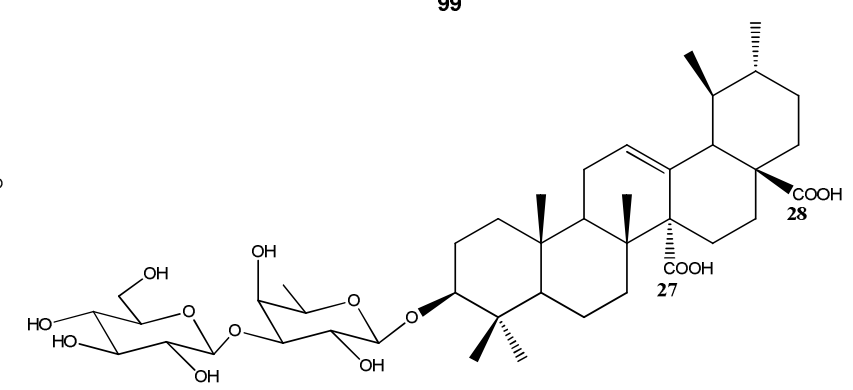

101

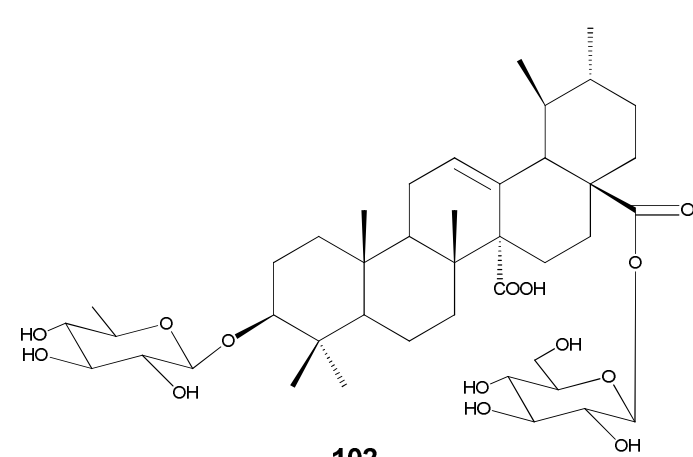

102

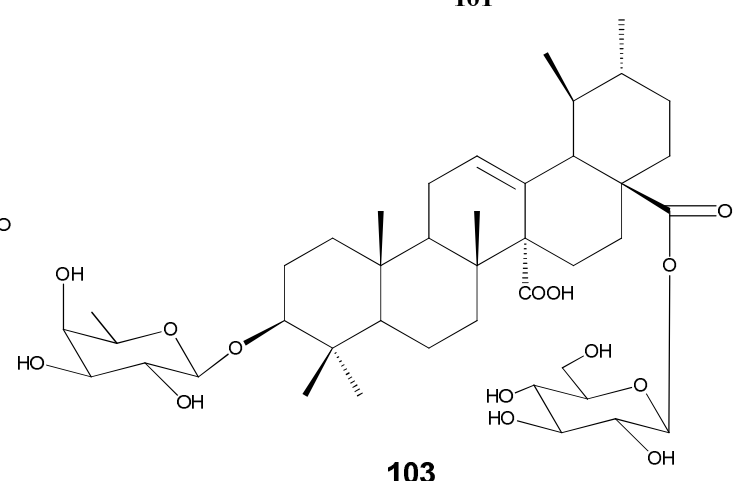

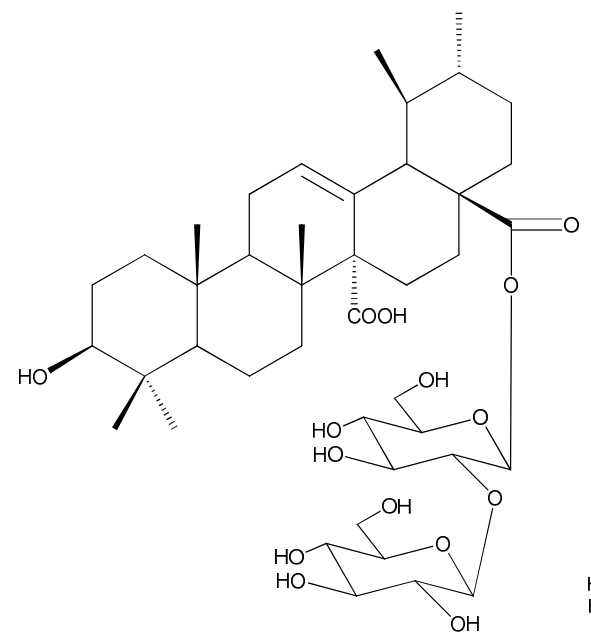

104

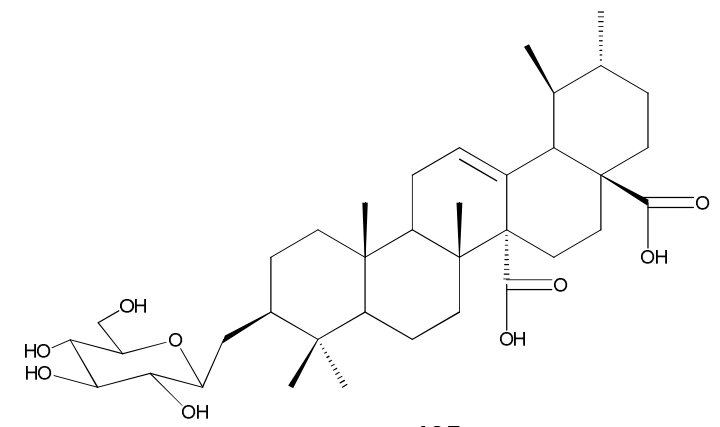




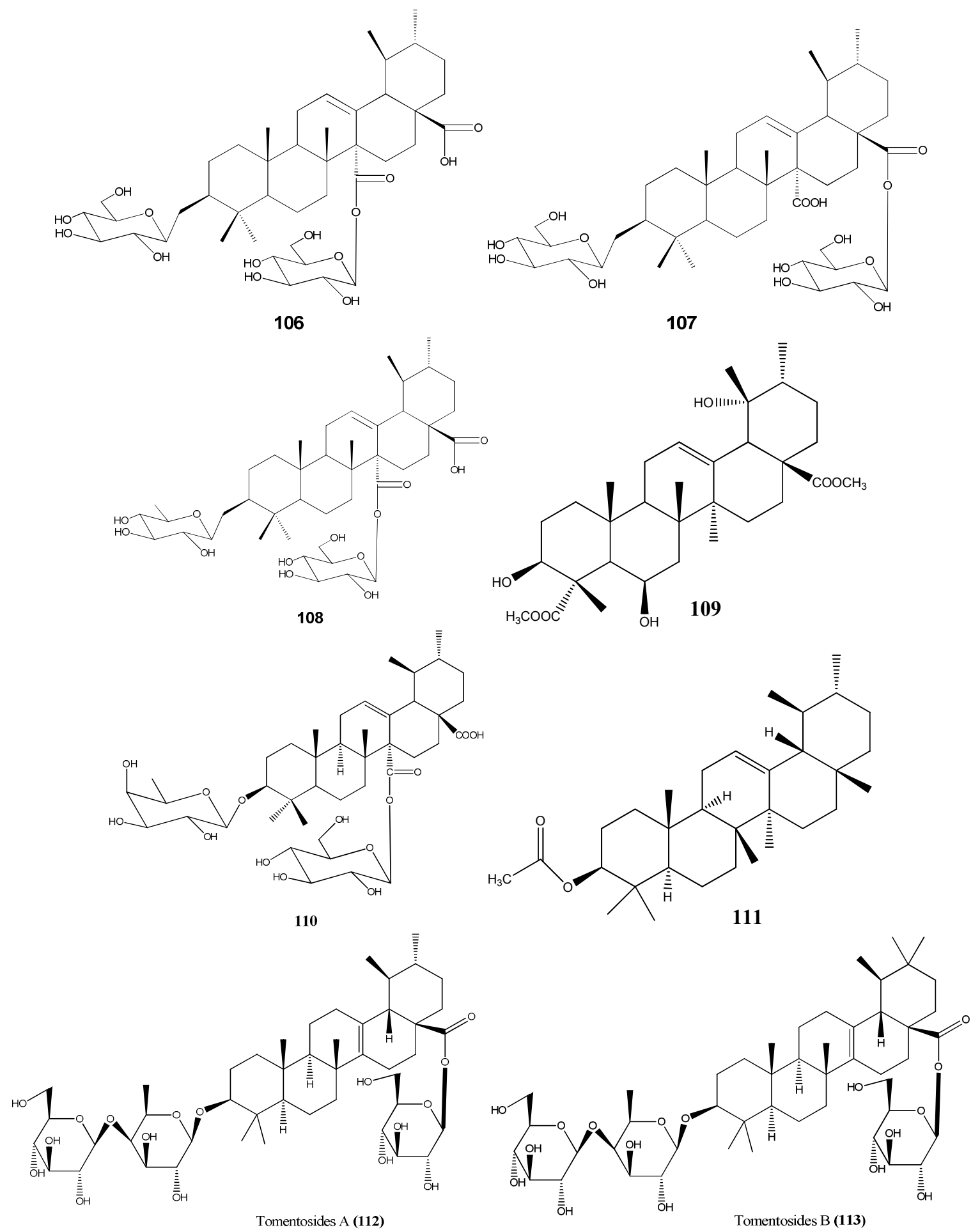

Figure 3. Pentacyclic triterpenoids and triterpenes saponin 

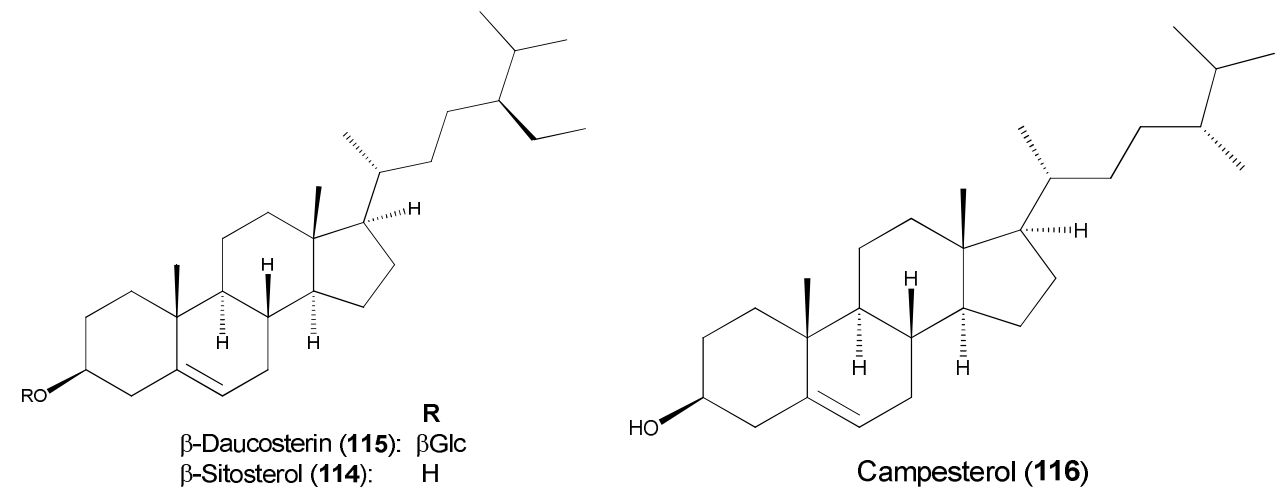

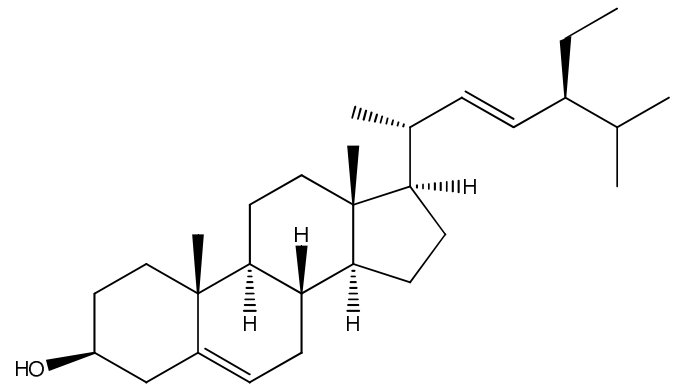

Stigmasterol (117)<smiles>O=c1ccc2ccc(O)cc2o1</smiles>

Umbelliferone (118)<smiles>COc1cc2ccc(=O)oc2cc1O</smiles>

Scopoletin (119)<smiles>COc1cc([C@@H]2c3c(cc(OC)c(O)c3OC)C[C@@H](CO)[C@H]2COC2OC3C(O)C(O)C(O)C3C2O)cc(OC)c1O</smiles>

120<smiles>COc1cc([C@@H]2c3c(cc(OC)c(O)c3OC)C[C@@H](CO)[C@H]2COC2OC3C(O)C(O)C(O)C(C2O)C3O)cc(OC)c1O</smiles>

121<smiles>COc1cc([C@@H]2c3c(cc(OC)c(O)c3OC)C[C@@H](CO)[C@H]2COC2OC3C(O)C(O)C(O)C(O)C3O2)cc(OC)c1O</smiles>

122<smiles>COc1cc([C@H]2c3c(cc(OC)c(O)c3OC)C[C@@H](CO)[C@H]2COC2OC3C(O)C(O)C(O)C(O)C3O2)cc(OC)c1O</smiles>

123

Figure 4. Sterols, coumarins and lignans 


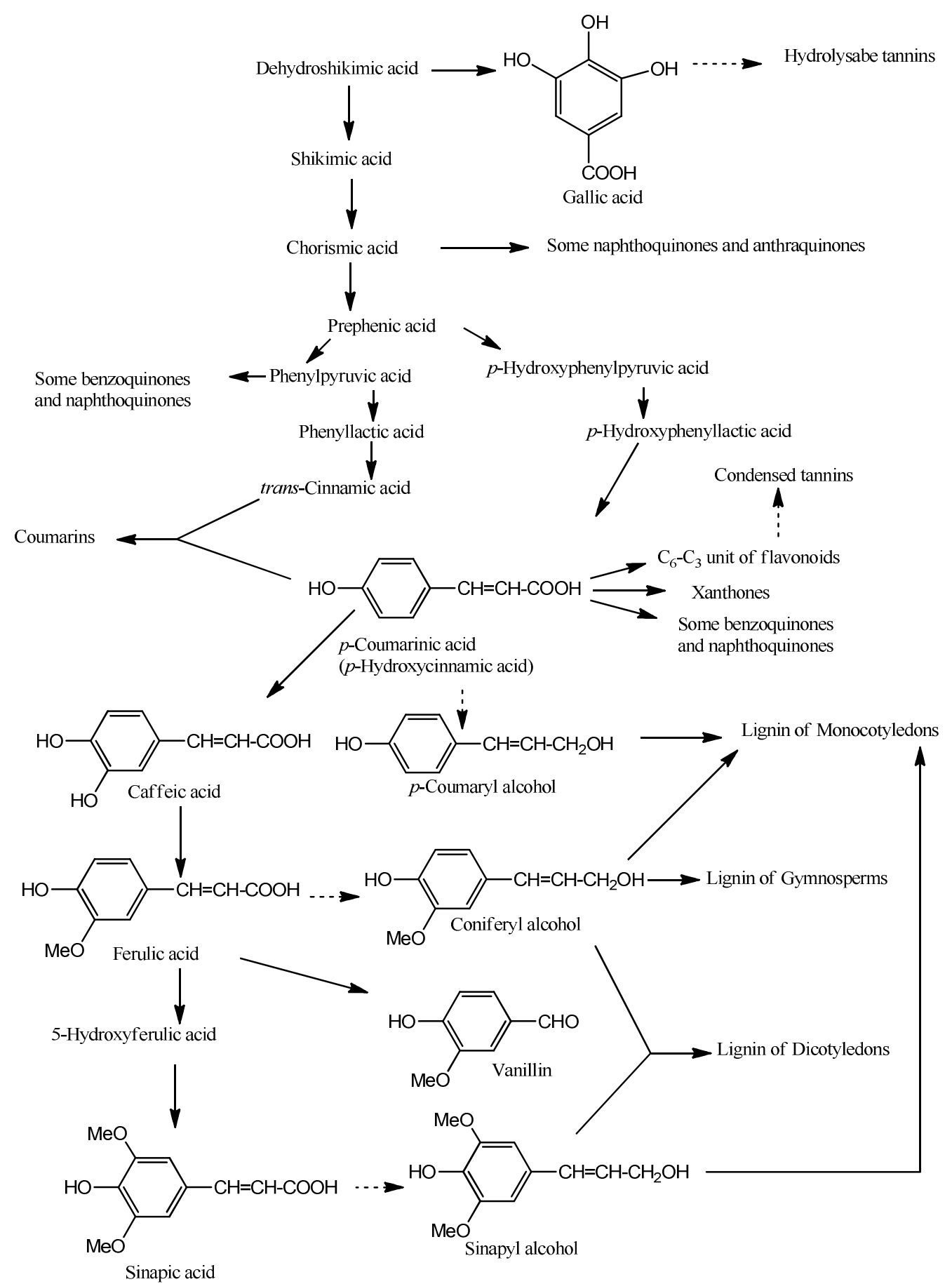

Scheme 1. Main steps of the shikimic acid pathway leading to cinnamic acids and their derivatives 

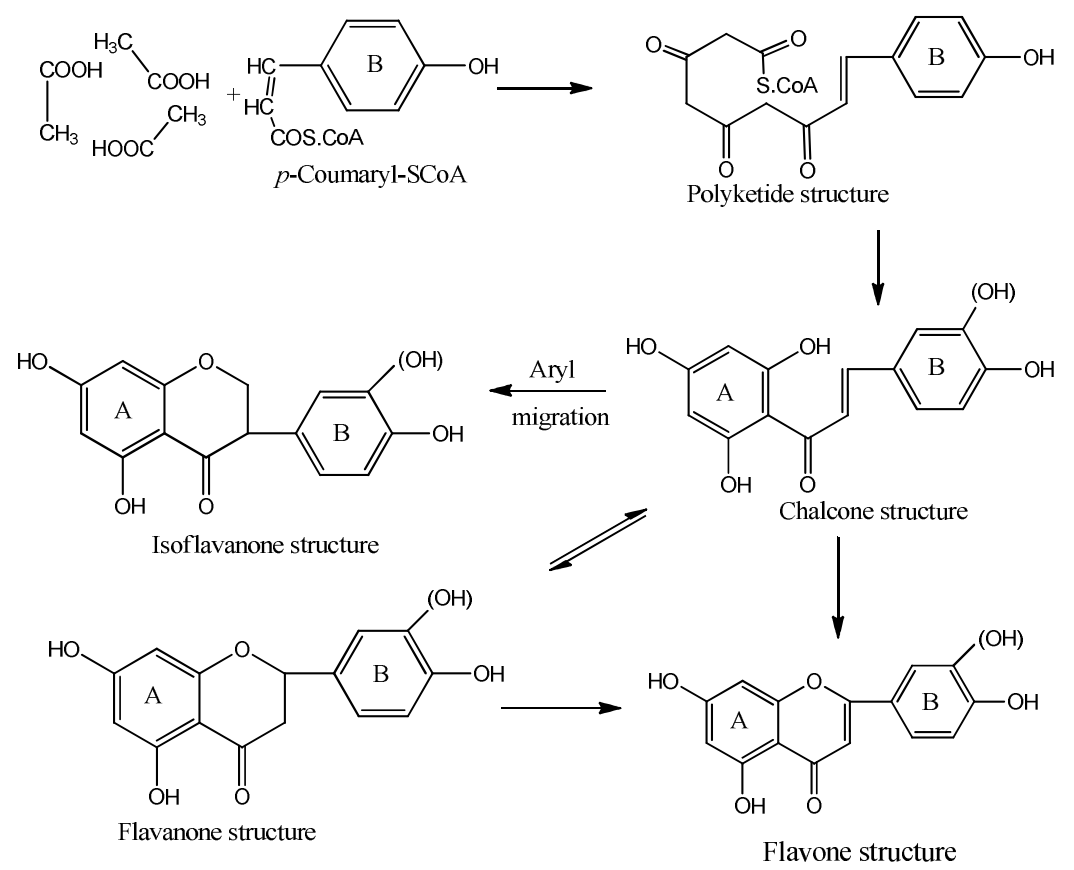

Scheme 2. Main step of the flavonoid biosynthesis

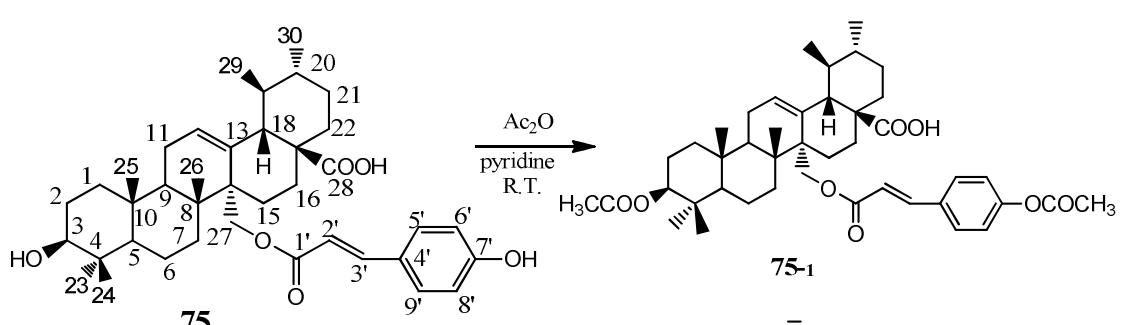

75
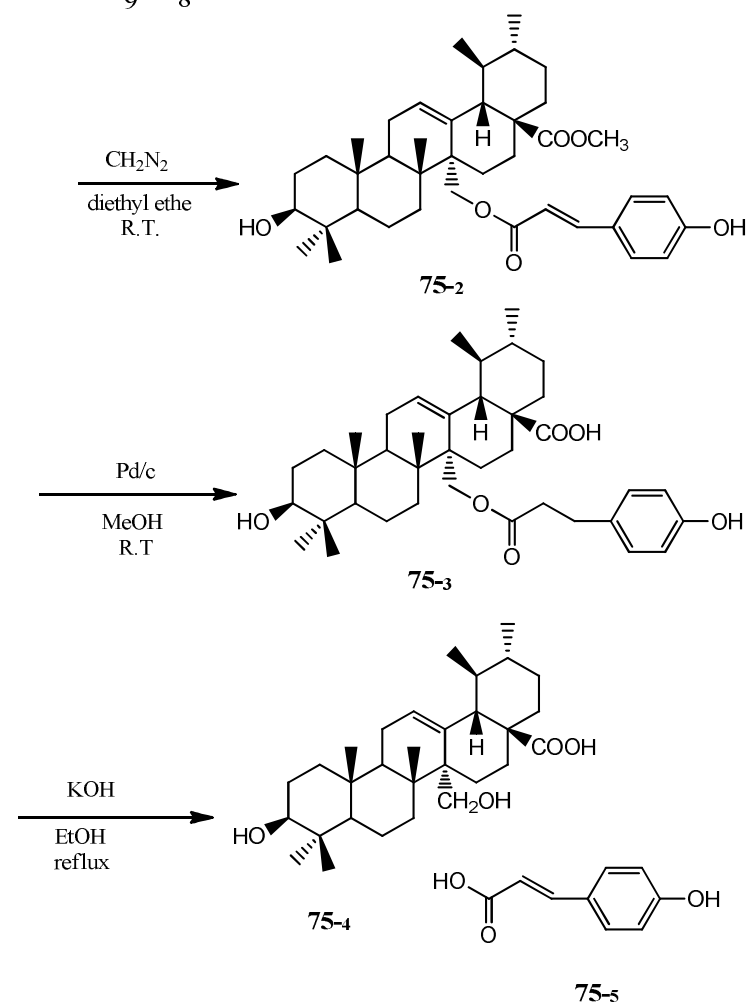

Scheme 3. Structure-activity relationship of 33-hydroxy-27-p-E-coumaroyloxyurs-12-en-28-oic acid derivatives (75) 


\section{References}

[1] Heitzman ME, Neto CC, Winiarz E, Vaisberg AJ, Hammond GB. Phytochemistry 2005; 66: 5-29.

[2] Keplinger K, Laus G, Wurm M, Dierich MP, Teppner H. J Ethnopharmacol 1998; 64: 23-34.

[3] Ndagijimana A, Wang X, Pan G, Zhang F, Feng H, Olaleye O. Fitoterapia 2013; 86: 35-47.

[4] Shi J-S, Yu J-X, Chen X-P, Xu R-X. Acta Pharmacol Sin 2003; 24: 97-101.

[5] Sun G, Zhang X, Xu X, Yang J, Lixun L, Zhong M. J Med Plants Res 2012; 6: 2200-2205.

[6] Ma B, Liu S, Xie Y, Kano Y, Yuan D. Asian J Trad Med 2009; 4: 85-91.

[7] Muhammad I, Dunbar DC, Khan RA, Ganzera M, Khan IA. Phytochemistry 2001; 57: 781-785.

[8] Li SG, Dong XX, Shan YJ, Liang ZM, Xun LL, Yuan JQ. J Med Plants Res 2011; 5: 4962-4967.

[9] Beecher GR. J Nutr 2003; 133: 3248S-3254S.

[10] Iwashina T. J Plant Res 2000; 113: 287-299.

[11] Torssell KBG. Great Britain: John Wiley and Sons Limited; 1983. p. 1-373.

[12] Kitajima M, Hashimoto K-i, Sandoval M, Aimi N, Takayama H. Chem Pharm Bull 2004; 52: 1258-1261.

[13] Lee JS, Kim J, Kim BY, Lee HS, Ahn JS, Chang YS. J Nat Prod 2000; 63: 753-756.

[14] Evans W, Trease, Evans. Pharmacognosy WB Saunders, Harcourt Publishers Limited; 2002. p. 214-253.

[15] Brunetton J. Pharmacognosy. Lavoisier publishing, Paris; 1999. p. 200- 403.

[16] Stalikas Constantine D. J Sep Sci 2007; 30: 3268-3295.

[17] Valente LMM, Bizarri CHB, Liechocki S, Barboza R, S. , P. Dd, Almeid MBS, et al. J Braz Chem Soc 2009; 20: 1041-1045.

[18] Senatore A, Cataldo A, Iaccarino F, Elberti M. Boll Soc Ital Biol Sper 1989; 65: 517-520.

[19] Aquino R, Vincenzo dF, Francesco dS, Cosimo P, Giuseppe C. J Nat Prod 1991; 54: 453-459.

[20] Aquino R, De Tommasi N, De Simone F, Pizza C. Phytochemistry 1997; 45: 1035-1040.

[21] Aimi N, Shito T, Fukushima K, Itai Y, Aoyama C, Kunisawa K, et al. Chem Pharm Bull 1982; 30: 4046-4051.

[22] Han J, Oh S, Kim H, Park Y, Baek N. J Korean Soc Agric Chem Biotechnol 2000; 43: 78-80.

[23] Zhu M, Phillipson JD, Yu H, Greengrass PM, Norman NG. Phytother Res 1997; 11: 231-236.
[24] Li SG, Dong XX, Shan YJ, Liang ZM, Xun LL, Yuan JQ. J Med Plants Res 2011; 5: 4962-4967.

[25] Aquino R, De Simone F, Vincieri FF, Pizza C, Gaćs-Baitz E. J Nat Prod 1988; 51: 251-561.

[26] Aquino R, De Simone F, Pizza C. J Nat Prod 1989; 52: 679-685.

[27] Apea-Bah F, Hanafi M, Dewi R, Fajriah S, Darwaman A, Artanti N, et al. J Med Plants Res 2009; 3: 736-757.

[28] Taniguchi S, Kuroda K, Doi K, Inada K, Yoshikado N, Yoneda Y, et al. Yakugaku zasshi 2007 a; 127: 1291-1300.

[29] Kim Y-M, Jeong Y-K, Wang M-H, Lee W-Y, Rhee H-I. Nutrition 2005; 21: 756-761.

[30] Wang X, Mao Y, Wang N-L, Yao X. Molecules 2008; 13: 2796-2803.

[31] Kim Y-S, Hwang J-W, Kim S-E, Kim E-H, Jeon Y-J, Moon S-H, et al. Biotechnol Bioproc E 2012; 17: 1213-1222.

[32] Zhao Q, Watanabe Y, Sakakibara I, Zhang S, Murakami T, Higashida M, et al. Med Pharm Soc Wakan-Yaku 2002; 8: Suppl 152.

[33] Al-Musayeib N, Perveen S, Fatima I, Nasir M, Hussain A. Molecules 2011; 16: 10214-10226.

[34] Amaral S, Mira L, Nogueira JMF, Silva APd, Helena Florêncio M. Bioorg Med Chem 2009; 17: 1876-1883.

[35] Yoshikawa M, Shimada H, Shimoda H, Murakami N, Yamahara J, Matsuda H. Chem Pharm Bull 1996; 44: 2086-2091.

[36] Nakazawa T, Banba K-i, Hata K, Nihei Y, Hoshikawa A, Ohsawa K. Biol Pharm Bull 2006; 29: 1671-1677.

[37] Lambert JD, Hong J, Yang G-y, Liao J, Yang CS. Am Soc Clin Nutr 2005; 81: S284-S291.

[38] Gulcin I, Alici HA, Cesur M. Chem Pharm Bull 2005; 53 : 281-285

[39] Lee M-W, Lee Y-A, Park H-M, Toh S-H, Lee E-J, Jang H-D, et al. Arch Pharm Res 2000; 23: 455-458.

[40] Fabiyi OA, Atolani O, Adeyemi OS, Olatunji GA. Asian Pac J Tropical Biomed 2012; 2: S981-S984.

[41] Heim KE, Tagliaferro AR, Bobilya DJ. J Nutr Biochem 2002; 13: 572-584.

[42] Škerget M, Kotnik P, Hadolin M, Hraš AR, Simonič M, Knez Ž. Food Chem 2005; 89: 191-198.

[43] Van Acker Sabe, de Groot MJ, van den Berg D-J, Tromp MNJL, Donné-Op den Kelder G, Van der Vijgh WJF, et al. Chem Res Toxicol 1996; 9: 1305-1312.

[44] Yasuko K, Tomohiro N, Sei-Itsu M, Ai-Na L, Yasuo F, Takashi T. Biochim Biophys Acta 1984; 792: 92-97.

[45] Sekiya N, Shimada Y, Shibahara N, Takagi S, Yokoyama K, Kasahara Y, et al. Phytomedicine 2002; 9: 636-640.

[46] Law KH, Das NP. J Nat Prod 1990; 53: 125-130. 
[47] Yamaguchi F, Ariga T, Yoshimura Y, Nakazawa H. J Agr Food Chem 2000; 48: 180-185.

[48] Kim HY, Kim K. J Agr Food Chem 2003; 51: 1586-1591.

[49] Zhao X, Zhang X. J Med Plants Res 2009; 3: 776-784.

[50] Kampa M, Nifli A, Notas G, Castanas E. Rev Physiol Biochem Pharmacol 2007; 159: 79-113.

[51] Kanazawa K, Uehara M, Yanagitani H, Hashimoto T. Arch Biochem Biophys 2006; 455: 197-203.

[52] Haza AI, Coto AL, Morales P. Food Nutr Sc 2011; 2: 356-365.

[53] Sun G, Chu J, Han S, Xu X, Yang Jh, Liun L, et al. J Med Plants Res 2012; 6: 2206-2209.

[54] Fan C-Q, Yue J-M. Bioorg Med Chem 2003; 11: 703-708.

[55] Procházková D, Boušová I, Wilhelmová N. Fitoterapia 2011; 82: 513-523.

[56] Lee D, Jung H, Woo E-R. Arch Pharm Res 2005; 28 : $1031-1036$

[57] Siddiqui S, Siddiqui BS, Naeed A, Begum S. J Nat Prod 1990; 53: 1332-1336.

[58] Lee JS, Yang MY, Yeo H, Kim J, Lee HS, Ahn JS. Bioorg Med Chem Lett 1999; 9: 1429-1432.

[59] Lee JS, Yoo H, Suh YG, Jung JK, Kim J. Planta Med 2008; 74: 1481-1487.

[60] Umeyama A, Yahisa Y, Okada M, Okayama E, Uda A, Shoji N, et al. J Nat Med 2010; 64: 506-509.

[61] Sun G, Zhang $\mathrm{X}, \mathrm{Xu} \mathrm{X}$, Yang J, Zhong M, Yuan J. Molecules 2012; 17: 504-510.

[62] Sun G, Zhang X, Xu X, Yang J, Zhong M, Yuan J. Molecules 2012; 17: 1883-1889.

[63] Somova LO, Nadar A, Rammanan P, Shode FO. Phytomedicine 2003; 10: 115-121.

[64] Kazmi I, Gupta G, Afzal M, Anwar F. Asian Pacific Journal of Tropical Disease 2012; 2, Supplement 1: S453-S456.

[65] Higuchi CT, Pavane FR, Fujimura CQ. Quim Nova 2008; 31 : 1719-1721.

[66] Fa G, Fanli Z, Siguo L, Na G, Haiqing Y, Yu S, et al. J Med Microbiol 2010; 59: 567-572.

[67] Cantrell C, Franzblau S, Fischer N. Planta Med 2001; 67: 685-694.
[68] Wu TS, Chan YY. J Chin Chem Soc (Taipei Taiwan) 1994; 41: 209-212.

[69] Guangli S, Jinxiu C, Shuying H, Xudong X, Junshan Y, Lixun L, et al. J Med Plants Res 2012; 6:

[70] Kassim JM, Hussin HM, Achmad A, Dahon HN, Suan KT, Hamdan SH. Majalah Farmasi Indonesia ( Indones J Pharm) 2011; 22: 50-59.

[71] Cai Y, Luo Q, Sun M, Corke H. Life Sci 2004; 74: 2157-2184.

[72] Krishnaiah D, Sarbatly R, Nithyanandam R. Food Bioprod Process 2011; 89: 217-233.

[73] Štěrbová D, Matějičck D, Vlček J, Kubáň V. Anal Chim Acta 2004; 513: 435-444.

[74] Desmarchelier C, Mongelli E, Coussio J, Ciccia G. Phytother Res 1997; 11: 254-256.

[75] Wu T-Y, Chen C-P, Jinn T-R. Taiw J Obstet Gyne 2011; 50: 131-135.

[76] Taniguchi S, Kuroda K, Doi K-i, Tanabe M, Shibata T, Yoshida T, et al. Chem Pharm Bull 2007; 55: 268-272.

[77] Wirth C, Wagner H. Phytomedicine 1997; 4: 265-266.

[78] Das NP, Law KH. Uncaria elliptica: In Vitro Culture and the Production of Epicatechin and Rutin, in Medicinal and Aromatic Plants IV, Y.P.S. Bajaj, Editor, Springer Berlin Heidelberg; 1993. p. 427-440.

[79] Taniguchi S, Kuroda K, Doi K, Tanabe M, Shibata T, Yoshida T, et al. Heterocycles 2008; 76: 1171-1180.

[80] Wu J, Li G, Wang D. Nan Fang Yi Ke Da Xue Xue Bao 2007; 27: 226-227.

[81] Herath WHMW, Sultanbawa MUS, Wannigama GP. Phytochemistry 1978; 17: 1979-1981.

[82] Yang C-J, Zhang J, Wu D-G. Acta Metall Sin 1995; 17: 1-3.

[83] Xin W-B, Chou G-X, Wang Z-T. Helv Chim Acta 2009; 92: 638-644.

[84] Yépez AMP, de Ugaz OL, Alvarez CMP, De Feo V, Aquino R, De Simone F, et al. Phytochemistry 1991; 30: 1635-1637.

[85] Kitajima M, Hashimoto K, Yokoya M, Takayama H, Sandoval M, Aimi N. J Nat Prod 2003; 66: 320-323. 